\title{
Scales matter: maximising the effectiveness of interventions for pollinators and pollination
}

Article

Accepted Version

Creative Commons: Attribution-Noncommercial-No Derivative Works 4.0

Faichnie, R., Breeze, T. D. ORCID: https://orcid.org/00000002-8929-8354, Senapathi, D. ORCID: https://orcid.org/00000002-8883-1583, Garratt, M. P. D. and Potts, S. G. ORCID: https://orcid.org/0000-0002-2045-980X (2021) Scales matter: maximising the effectiveness of interventions for pollinators and pollination. Advances in Ecological Research, 64. pp. 105147. ISSN 0065-2504 doi:

https://doi.org/10.1016/bs.aecr.2020.11.003 Available at https://centaur.reading.ac.uk/96415/

It is advisable to refer to the publisher's version if you intend to cite from the work. See Guidance on citing.

To link to this article DOI: http://dx.doi.org/10.1016/bs.aecr.2020.11.003

Publisher: Elsevier

All outputs in CentAUR are protected by Intellectual Property Rights law, including copyright law. Copyright and IPR is retained by the creators or other copyright holders. Terms and conditions for use of this material are defined in the End User Agreement. 


\section{www.reading.ac.uk/centaur}

\section{CentAUR}

Central Archive at the University of Reading

Reading's research outputs online 


\title{
Scales matter: maximising the effectiveness of interventions for pollinators and pollination
}

\author{
Authors: Rachel Faichnie ${ }^{1}$, Tom D. Breeze ${ }^{1}$, Deepa Senapathi ${ }^{1}$, Mike P.D. Garratt ${ }^{1}$ and Simon G. Potts ${ }^{1 *}$ \\ ${ }^{1}$ Centre for Agri-Environmental Research, School of Agriculture, Policy and Development, University of \\ Reading, Reading, RG6 6AR, UK \\ *corresponding author, s.g.potts@reading.ac.uk
}

Running title: Scales matter for pollinator protection

Keywords: management and policy responses, pollination services, pollinator conservation, scalematching, spatial and temporal scales 


\section{Contents}

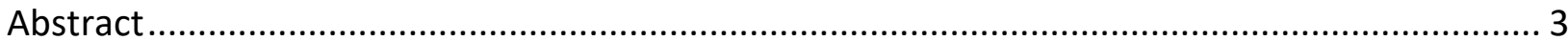

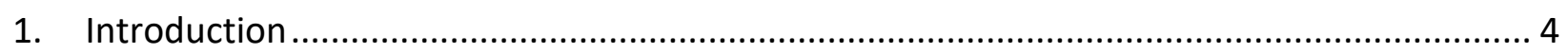

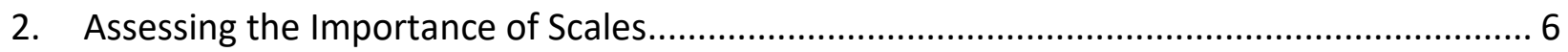

3. Scale Influences on the Effectiveness of Interventions for Pollinators and Pollination ......... 8

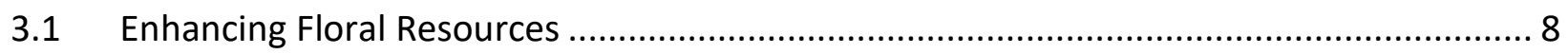

Enhancing the Wider Landscape........................................................................... 12

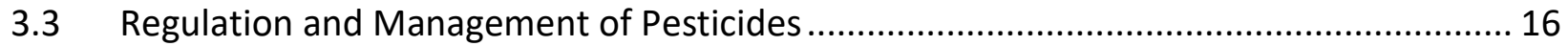

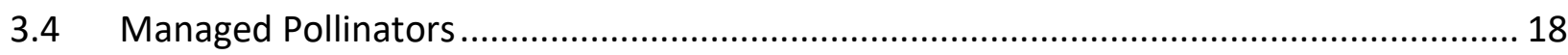

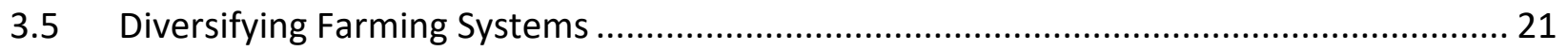

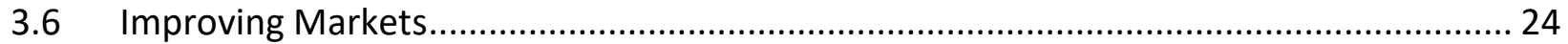

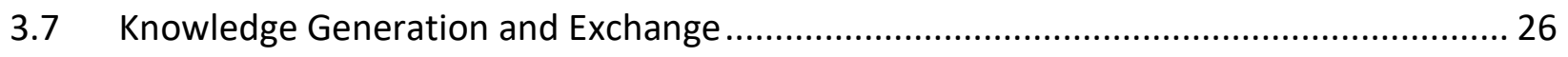

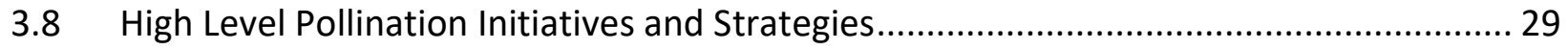

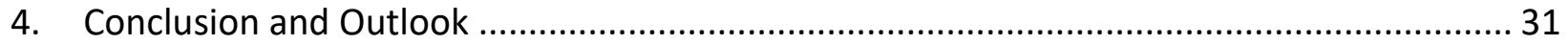

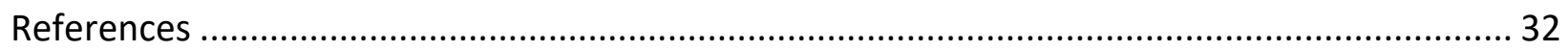




\section{Abstract}

Evidence of declines in wild and managed pollinators and pollination services is increasingly being documented around the world. This has driven the development of a wide range of practical management and policy responses which were reviewed in the Intergovernmental science-policy Platform on Biodiversity and Ecosystem Services (IPBES) global assessment of 'Pollinators, Pollination and Food Production'. We take 38 responses from this report as a basis to explore the importance of scale for the effective delivery of an intervention's benefit to pollinators. We considered five scale categories: Spatial, the spatial scale at which the response is most effective; Temporal, the time scale over which the response is most effective; Actors, the number of actors needed for most effectively implementing a response; Social, the sphere of influence or motivation that determines an effective response; and, Sector, the sector(s) of society which should be involved to increase effectiveness. Each scale category was split into multiple levels and we scored each in terms of how important they were for determining the effectiveness of a given response option. Using our combined scores, we aim to explore general trends and raise awareness around the main issues relating to the importance of scale, with illustrated examples from the literature. We show how scales have impacted on the effectiveness of interventions and provide recommendations on how to improve scale matching when planning a response action. While the relative importance of scales and levels for effectiveness was heterogeneous across response options, there were some general patterns. Interventions were only effective when targeted over the right spatial scales over a sufficient period of time and involved all relevant social and sectoral groups and actors. 


\section{INTRODUCTION}

There is a rapidly increasing body of knowledge on the status and trends of pollinators and the drivers linked to substantial declines in some wild pollinator taxa in several regions of the world (IPBES, 2016a). Our understanding of the role of land use change, climate change, agricultural intensification, pathogens and invasive alien species as drivers of declines are widely documented, though the impacts of multiple drivers, and their interactions, remains unclear (Gill et al. 2016; Potts et al. 2016; Vanbergen et al. 2013). There is increasing recognition of the wide range of economic and socio-cultural values pollinators bring to society stimulating calls from the public, growers, conservationists, scientists and policy makers for actions to protect and sustainably manage pollinators (Harvey et al. 2020). A diverse portfolio of management and policy response options exists, which were assessed comprehensively in the IPBES (2016a) assessment of 'Pollinators, Pollination and Food Production'. These included local habitat management in farms and cities, developing landscape-scale ecological infrastructure, improving training and technology for agrochemical inputs, capitalizing on local and indigenous knowledge of pollinator conservation, and developing policy frameworks to incentivize and regulate for better pollinator protection.

The IPBES report outlined key responses that could be implemented across multiple spatial scales, sectors and timespans, but there are outstanding challenges, and major knowledge gaps, remaining around how to most successfully operationalize these in practice. In particular, how can we maximise the effectiveness of responses accounting for spatial and temporal scales, and the number and type of actors, sectors, and social spheres of influence involved? Whether responses aim to improve current conditions for pollinators, transform landscapes, or enhance society's relationship with pollinators, the impact of different dimensions of 'scale' on the effectiveness of interventions and their outcomes is rarely considered in detail. We systematically address the influence of scales through a framework that explores multiple categories of scale, how these can change the effectiveness of interventions, and providing a way to ensure consideration of the appropriate scales during planning and implementation of interventions and responses. For instance, even if an intervention (e.g. a flower strip) is implemented at the appropriate spatial scale (e.g. field) and involving the right actor (farmers) and sectors (e.g. agrifood and policy), if the timeframe is insufficient (e.g. less than a year) then the intervention is unlikely to deliver any measurable benefits for pollinators because a key dimension of scale was inadequately considered. In this paper, we assess the influence of five scale categories: 
- Spatial, the spatial scale at which the response is most effective;

- Temporal, the time scale over which the response is most effective;

- Actors, is defined as a group of individuals with shared occupations or roles (e.g. farmer, beekeeper, nature reserve manager and politician), and this category considers the number of actors needed for most effectively implementing a response;

- Social, the sphere (or scale) of influence or motivation that determines an effective response. This is derived from social groups which may or may not include multiple actors and sectors, such as the influence of the immediate peer groups, all the way to the wider public opinion;

- Sector, is defined as a specific part or division of society or the economy, made up of similar elements (e.g. business, NGO, policy and public), and this category considers the types of sectors which should be involved to increase effectiveness.

Currently the most comprehensive global overview of pollinator interventions is the IPBES (2016a) assessment of 'Pollinators, Pollination and Food Production', and we use the table summarizing the responses (IPBES, 2016b; Table SPM.1) as the basis to assess the importance of the selected five scales, the responses have been grouped under eight broad themes:

1. Enhancing floral resources;

2. Enhancing the wider landscape;

3. Regulation and management of pesticides;

4. Managed pollinators;

5. Diversifying farming systems;

6. Improving markets;

7. Knowledge generation and exchange;

8. High level pollination initiatives and strategies.

We use examples of interventions where scale is known to have impacted effectiveness, highlighting successes and failures, and provide recommendations on how to improve scale matching when planning 
an intervention. Inevitably there is some overlap between themes, however, we aim to provide an overview of the wide range of interventions identified by IPBES (2016a) and indicate where an intervention falls within more than one theme.

\section{ASSESSING THE IMPORTANCE OF SCALES}

The IPBES (2016b) report provides an overview of 39 strategic responses to risks and opportunities associated with pollinators and pollination and classified these into three broad approaches: (i) Improving current conditions for pollinators and/or maintaining pollination by managing the immediate risks and utilizing immediate opportunities; (ii) Transforming agricultural landscapes by ecologically intensifying agriculture through active management of ecosystem services, strengthening existing diversified farming systems and investing in ecological infrastructure (Vanbergen et al THIS VOLUME); and (iii) Transforming society's relationship with nature, which includes integrating peoples' diverse knowledge and values into management and linking people and pollinators through collaborative, crosssectoral approaches. The IPBES table (SPM.1 in IPBES 2016b) itself is not exhaustive, and includes about half of the interventions documented in the main technical report (2016a), but it represents the broad diversity of responses including some of the most commonly adopted. We added one additional response 'Plant breeding solutions to reduce reliance on biotic pollination'. This was originally included in the IPBES (2016b) table but was removed in the penultimate draft during the science-policy dialogue process due to strong opposition by one IPBES signatory government. The full list of responses used in this paper and their full definitions are given in Supplementary Materials (SM1).

To explore the issue of scale, the authors of this paper independently scored each response to assess the different levels of scale within each category in terms of how important they were for determining the effectiveness of a response option. For instance, spatial scale has five levels: field, farm, landscape, national and global. The definitions of the scale categories and the levels within each scale category are given in Table 1.

[INSERT TABLE 1 HERE]

Importance was defined as the extent to which a particular level (e.g. farm or other land unit) within a given scale category (e.g. spatial) determines the effectiveness of an intervention in terms of benefits to 
pollinator conservation or sustainable management of pollination services. Importance scores were assigned as: 'no importance or relevance' (score $=0$ ), 'low or some importance' (score $=1$ ), or 'high importance' (score $=2$ ). The scores for the five authors were then summed for each response scale category level cell, to provide an overall score between 0 and 10, and raw scores are provided in Supplementary Materials (SM2).

Based on the scoring process we made a minor change to the list of responses to remove three that we considered overly broad because they combined multiple types of interventions, which made it too difficult to score consistently using our framework. However, all the individual interventions listed within these three broad responses are captured within other responses in the IPBES table (2016b). The three responses removed were: (i) 'Patchiness, crop rotation and co-production of knowledge between indigenous and local knowledge holders, scientists and stakeholders', which is covered by 'Support diversified farming systems' and 'Support knowledge co-production and exchange'; (ii) 'Support organic farming systems; diversified farming systems; and food security, including the ability to determine one's own agricultural and food policies, resilience and ecological intensification', which is covered by 'Reduce pesticide use', 'Support diversified farming systems', 'Traditional and knowledge co-production for habitat management' and 'Support knowledge co-production and exchange'; and, (iii) 'Support largescale land-use planning and traditional practices that manage habitat patchiness and biocultural diversity', which is covered by 'Collaborative approaches to landscape management', 'Increase connectivity between habitat patches' and 'Support "biocultural diversity" conservation approaches'. The final list therefore comprised 38 responses and the full definitions and their shortened forms are given in Supplementary Materials (SM1).

After the initial round of scoring, all authors independently reviewed the table and identified any major differences between individual and overall group scores. The authors then met to discuss these differences to reach a consensus score as a group considering available evidence. Of the 798 scoring cells in the table ( 21 levels $x 38$ responses) only six scores were adjusted $(<1 \%)$. Both the original score and adjustments made are described in Supplementary Materials (SM2).

Our approach aimed to be a preliminary assessment focusing on the importance of scale and we recognize there are a number of caveats that go with this. First, there were only five assessors involved and the process could have benefited from a larger group with more diverse knowledge and a more formal scoring and consensus approach (e.g. Delphi panels where experts are surveyed independently 
on a topic, then asked to discuss their answers before rescoring their responses until consensus is reached; Mukherjee et al. 2015). However, the authors share >90 years of collective experience of working with pollinators, possess extensive expertise relevant to this assessment (ecological science, pollination economics, policy and practice, societal engagement) and two authors were heavily involved in the IPBES pollination assessment as a Co-chair and a Lead Author. Secondly, the Table SPM.1 in IPBES (2016b) is not an exhaustive list of responses, and there has been new knowledge generated since 2016. More data would be needed for a detailed quantitative analysis of scale across all interventions and to present such a thorough review of the evidence is not the aim of this paper. Instead, we aim to explore trends, and raise awareness of the main issues around the importance of scale in responding to the impacts of human activities on pollinators and pollination through a variety of illustrative examples from the IPBES assessment (IPBES, 2016a) and more recent studies.

\section{SCALE INFLUENCES ON THE EFFECTIVENESS OF INTERVENTIONS FOR POLLINATORS AND POLLINATION}

The relative importance of different scale categories and the levels within a scale category were heterogeneous across the range of response options and themes (Table 2). Several patterns emerged and these are highlighted, along with their implications for pollinator conservation and sustainable management, in our eight themes.

[INSERT TABLE 2 HERE]

\subsection{Enhancing Floral Resources}

Responses assessed:

- Create uncultivated patches of vegetation

- Restore natural habitats

- Manage road verges

- Manage rights of way and vacant land in cities

- Manage urban spaces for pollinators and collaborative pathways 
There is strong evidence that reduced floral resource availability is an important limiting factor for bee populations (e.g. Carvell et al. 2015; Carvell et al. 2017; Roulston and Goodell, 2011), and so enhancing floral resources has become a focus of many pollinator conservation efforts. Flower-rich habitat can provide sources of nectar and pollen for pollinators throughout an extended flowering period and can directly enhance the connectivity and complexity of landscapes (Kovács-Hostyánszki et al. 2017) [see section 3.2]. Enhancing floral resources can promote higher pollinator abundance and richness and can subsequently provide improved crop pollination services (Gill et al. 2016). However, pollinator biodiversity and pollination services can also exhibit diverging responses to farm management actions. For instance, Nicholson et al. (2020) showed that florally enhanced field edges harbored bee communities that were more abundant, diverse (taxonomically and functionally) and compositionally distinct than in control edges. These floral enhancements did not increase the abundance or diversity of bees visiting crops, indicating that the supply of pollination services might differ between edge and center of fields and highlighting the differences in effectiveness based on spatial location. From the overview included in the IPBES table (IPBES, 2016b), the strategic responses involving the enhancement of floral resources are creating uncultivated patches of vegetation, managing road verges, managing rights of way and vacant land, restoring natural habitats and managing urban spaces for pollinators. Based on our assessment, the most important scales to consider when implementing floral enhancement measures are spatial and temporal scales. Farmer-level interventions (e.g. field margins) are largely implemented at smaller scales over the shorter term, whereas floral enhancement in conjunction with transport infrastructure and urban spaces generally operate at larger spatial scales over a longer timeframe (Table 2).

In agricultural landscapes, portions of farmland can be left uncultivated and flower-rich areas such as sown field margins, hedgerows and wildflower strips can be established. Wildflower strips can enhance pollinator diversity and abundance at both local and landscape spatial scales (Jönsson et al. 2015; Kovács-Hostyánszki et al. 2017) however, these scale-dependent effects may differ between different pollinator groups (Jönsson et al. 2015). At larger spatial scales, the effectiveness of these practices can be moderated by the extent of uptake by farmers (Baude et al. 2016) and landscape context, with a greater likelihood of effectiveness in simple landscapes (defined as 1-20\% semi-natural habitat) compared to more complex landscapes (>20\% semi-natural habitat) (Scheper et al. 2013). Moreover, the distance from florally rich areas can moderate the delivery of crop pollination services by wild pollinators (Garibaldi et al. 2011). Enhancing flower-rich areas in agroecosystems can provide short-term 
benefits for pollinators. Evidence shows that such actions can enhance wild bumblebee reproductive success (Carvell et al. 2015) and colony survival (Carvell et al. 2017). However, the effectiveness of these practices for increasing pollinator populations over the longer term is not well-understood. There is evidence that uncropped flower-rich areas can also promote pollination services to agricultural crops; however, effectiveness may be moderated by spatial scale [see section 3.2]. For example, Pywell et al. (2015) showed that the yield of field bean Vicia faba at the farm-scale can be increased by $25 \%$ and $35 \%$ where $3 \%$ and $8 \%$ of the area, respectively, was converted to wildflower strips and other semi-natural habitat. Sown field margins can provide high sources of nectar and pollen seasonally, although, a recent European-wide analysis suggests that seasonal temporal trends can strongly differ geographically (Cole et al. 2020). Cole et al. (2020) also highlighted that field margins across Europe generally lack flowers that provide nectar and/or pollen resources for pollinators later in the season. Designing flower mixes to provide temporal resource continuity throughout the season is vital for supporting pollinator communities within these flower-rich areas (Scheper et al. 2015) and so future seed mixes should be developed to assure a succession of pollen and nectar sources over a few years. Moreover, future plantings should be designed to support bee and non-bee pollinators (see Howlett et al. THIS VOLUME), as sown flower strips are often tailored towards common bumblebee species and can fail to support the majority of pollinator taxa (Wood et al. 2017). Hedgerow restoration schemes that provide pollinators with floral and nesting resources over many years may be a more effective measure for promoting pollinator populations in the long-term than annual wildflower strips. M'Gonigle et al. (2015) successfully showed that restoring flowering hedgerows that bordered larger crop fields in the Central Valley of California, USA, increased pollinator species richness at the local farm scale over an eight-year period. Overall, the creation of uncultivated vegetation currently tends to operate over the shorterterm, at field to landscape scales, with the involvement of a single actor (landowner i.e. farmer).

Roads and other 'rights of way' infrastructure (railway embankments, powerlines, pipelines, rivers and canals) are interwoven throughout rural and urban landscapes and have the potential to provide valuable additional linear habitat for insect pollinators (Wojcik and Buchmann, 2012). They can act as corridors, at least for some pollinator taxa (Moroń et al. 2017) and improve habitat connectivity across the wider landscape [see section 3.2]. As these linear habitats cover such a large extent of the landscape (Wojcik and Buchmann, 2012) it is likely that they would be effective at supporting pollinator communities, particularly when managed at larger spatial scales. Other scales can also influence the effectiveness of linear habitat management, for example, the number and types of actors is important 
for success (e.g. landowners, transportation agencies, researchers, academics, conservation organisations, and the public). In Minnesota, USA, through the coalition of multiple actors, thousands of acres worth of roadside prairie grassland has been enhanced, with the aim of creating valuable habitat for the Monarch butterfly and other native wildlife (Minnesota DNR, 2020). Although managing habitats associated with transport or other infrastructure has been recognised as a way to connect habitats and support pollinator communities, few policy strategies are currently in place to institute coordinated efforts for their management at the landscape scale (IPBES, 2016a). It should be noted that current evidence on the effects 'rights of way' habitat to support pollinators over long timescales is scarce, with most studies limited to $\leq 2$ years (Villemey et al. 2018).

From our assessment, we concluded that the enhancement of flower-rich habitat in urban spaces tends to operate at landscape and national scales (Table 2 ) and usually involves a multi-actor and multi-sector approach [see section 3.2]. City-scale plant-pollinator network robustness can be increased through the enhancement of urban floral resources, as shown by Baldock et al. (2019). This study modelled the effect of increasing floral resources in parks, road verges and other greenspaces across four geographically distant UK cities and predicted that adding three abundant and commonly visited plant species to the different green spaces will increase city-scale plant-pollinator robustness (Baldock et al. 2019). Moreover, Baldock et al. (2019) found that the number of bee visits were greater in residential gardens and allotments than any other land use type, and when scaled up to city level, $54-83 \%$ of flower visits by pollinators occurred in residential gardens. Enhancing flower-rich areas in existing urban green spaces through gardener education and engagement and through coordinated management practices in public green spaces can scale up to create a network of high-quality urban spaces that can support abundant and diverse pollinator communities across cities (Aronson et al. 2017). The collaboration between a diverse set of actors (e.g. urban planners, developers, academics, researchers, policymakers, gardeners and the general public) across multiple sectors will likely maximise effectiveness at the city scale and ensure that urban spaces meet both the needs of pollinators and the socio-cultural needs of local residents. As the number of stakeholders increases, finding mutually agreeable management outcomes at larger spatial scales can become increasingly difficult, however, there are examples of success (River Revitalization Foundation Milwaukee, 2020; The National Pollinator Garden Network, 2019). In addition, many non-profit organisations (e.g. Buglife, 2020a; Pollinator Partnership, 2020a; Xerces Society, 2020) engage with the private and public landowners and promote planting pollinatorfriendly floral resources. 
There is sufficient evidence demonstrating that floral enhancement interventions can contribute towards enhancing pollinator communities, and from our assessment of scale, we concluded that spatial and temporal scales are of critical importance when implementing such actions. In addition, the inclusion of multiple appropriate actors can play an important role in the effective implementation of large-scale floral enhancement (e.g. in urban spaces and transportation links). Exactly what levels of spatial and temporal scale the different interventions for floral enhancement should be implemented at in terms of efficacy in supporting pollinators in the future landscape remains poorly understood and further requires long-term research.

\subsection{Enhancing the Wider Landscape}

Responses assessed:

- Restore natural habitats

- Increase connectivity between habitat patches

- Change grassland management

- Manage road verges

- Manage rights of way and vacant land in cities

- Manage urban spaces for pollinators and collaborative pathways

- Protect heritage sites and practices

Land degradation has resulted in biodiversity declines and in the disruption of ecosystem function and services worldwide (IPBES, 2018). Habitat restoration is a key measure to counteract negative impacts on biodiversity from habitat loss and fragmentation (Winsa et al. 2017) and forms an integral part of enhancing wider landscapes. There is evidence from both urban and rural environments to suggest that landscape management measures can contribute towards enhancing and restoring pollinator communities (Senapathi et al. 2017). However, the spatial scales at which each intervention is most effective may vary with each option. Whilst initiatives such as restoring natural habitats and managing urban spaces for pollinators needs to happen at a large spatial scale (i.e. local, national or regional scale), management responses such as increasing habitat connectivity or changing grassland 
management need to be highly local and can be effective at the farm scale or even at the field level (see Table 2).

Some of the interventions outlined above clearly overlap with measures for enhancing floral resources [section 3.1]. For example, the widely adopted practice in Europe and North America of planting flowering shrubs and forbs along field edges ( $M^{\prime}$ Gonigle et al. 2017) with positive impacts on pollinator communities (Haaland et al. 2011; Hardman et al. 2016b) could be considered under both floral enhancements [section 3.1] and the wider landscape improvement categories. Wider landscape management could also involve improving floral and nesting resources in urban green spaces such as domestic gardens and allotments which have been shown to have a positive impact on pollinator communities (Baldock, 2020). Forest landscapes are also known to benefit pollinator communities and the pollination services of adjoining agricultural land but there still exist significant knowledge gaps in terms of management practices that can enhance pollinator communties in this specific landscape (Krishnan et al. 2020).

Another intervention with an overlap between the wider landscape and the floral resource themes is that of road verges. Roadside verges and hedges can provide hotspots of resources for pollinators in rural and urban landscapes and along motorways effectively contributing to greenspace connectivity (Free et al. 1975; O'Sullivan et al. 2017; Phillips et al. 2019). However, their benefits to pollinators can be reduced by heavy traffic pollution and summer verge cutting (Phillips et al. 2019). Diesel exhaust pollution has been shown to affect bee olfaction and reduce flower detection due to negative impacts on learning and memory (Lusebrink et al. 2015; Reitmayer et al. 2019). Conversely reduced mowing frequency could enhance biodiversity, aesthetics and pollination services, whilst delivering costs savings, thereby potentially being acceptable to the public (O'Sullivan et al. 2017). It is therefore crucial to consider not just the spatial scales, but also the timing of implementation and management of measures.

Studies of native bee richness and abundance indicate that many diverse communities of wild bees persist in urban landscapes, and that cities and towns can be important refuges for pollinator populations (Baldock et al. 2015, 2019; Hall et al. 2017). However, Hall et al. (2017) indicate that while advances in pollinator conservation in rural landscapes are proliferating across governance scales, only a few city councils (Baldock et al. 2015), local authorities (Hertfordshire Pollinator Strategy, 2019) and 
national governments (DEFRA, 2019) are targeting urban landscapes and funding such efforts. EU Life funded Urban Green projects in Italy and Poland, focused on improving the management of urban green spaces, have benefitted ecosystem services and biodiversity, including pollinators (Life Urban Green, 2018).

In addition to urban and rural environments, the IPBES report (IPBES, 2016a) as well as subsequent articles (Potts et al. 2016) have highlighted the importance of protecting local, national and regional heritage sites and practices as a means towards pollinator conservation. Examples of sites that recognize such approaches include the Coffee Cultural Landscape of Colombia; the Osun Sacred Grove protected by Yoruba peoples near Osogbo, Nigeria; and the Agave Landscape in Mexico (Hill et al. 2019). All of these involve management at large spatial scales with multiple actors from different sectors including local communities, industry and science contributing towards these efforts (Cely-Santos and Lu, 2019; Trejo-Salazar and Eguiarte, 2016).

The effectiveness of the actions depends on the actors and sectors involved and the time scales over which they are implemented or assessed. While the specific actions taking place at the field or farm scale (e.g. hedgerow or grassland management) can be a single actor decision making process predominantly driven by the landowner or farmer (Britt et al. 2011), landscape scale initiatives usually require a multi-actor, multi-sectoral approach. For example, governments commonly provide incentives to encourage farmers to adopt production techniques that allow biodiversity to coexist alongside agriculture (Scherr and McNeely, 2008). Initiatives such as 'The Landscapes for Wild Pollinators and Farm Wildlife' (Stafford 2018; Buglife, 2020b) project is providing free, tailored advice to farmers and landowners in the UK and brings together policy, delivery agencies and NGOs. Businesses including agrifood may also be involved in enhancing landscape management through their influence on grower and supply chains to implement pollinator friendly management measures. Certification schemes such as 'Bee Friendly Farming' (Pollinator Partnership, 2020b) or 'Bee Better Certified' (Xerxes Society, 2020a) provide specialist advise to growers or farmers on pollinator habitat management and reduced pesticide use (Herrick, 2017), while others such as 'Fair to Nature Conservation Grade' (Fair to Nature, 2020) aimed at wider biodiversity could also aid pollinator communities as a consequence (Hardman et al. 2016a). 
While spatial scales may be the most important consideration, it should also be noted that different interventions will operate over different time scales. Field and farm level enhancements even within a wider landscape management context, may occur on a seasonal or annual basis, or even over the course of agri-environment scheme assessment timelines (e.g. 5-10 years); for instance, evidence suggests that the timing of mowing within a season in grassland management can significantly impact pollinator communities (Johansen et al. 2019). Policy timeframes in contrast, are more likely to operate on a five to ten-year timeframe, such as the many national pollinator strategies and action plans that currently exist (European Commission, 2020; National Biodiversity Data Centre, 2020; Rijksoverheid, 2018; SAPOLL, 2019; Senapathi et al. 2017) [see section 3.8]. Pollinators may also benefit from habitat restoration and protection measures incorporated in national and international Biodiversity 2020 plans as well as international conventions such as the CBD's specific Aichi targets (CBD, 2013) which operate on a decade long cycle.

Enhancing the wider landscapes generally works in terms of the "bigger, better and more joined up" approach as popularised by the 'Making Space for Nature' report (Lawton et al. 2010). However, whilst the spatial scales and associated timelines are taken into consideration, the question of where best to target actions, remains an open one. Evidence suggests that restoration actions should be targeted to sites near potential source populations of pollinators in the landscape to ensure that more species with limited mobility (e.g. many solitary bee species) can recolonize the restored habitat patches (Öckinger et al. 2018). This requires prior knowledge of where extant source populations are or are likely to exist in order to best target interventions in the right places. When planning restoration actions, it is also important to consider that species with certain traits (e.g. high resource specialisation) are unlikely to colonize restored sites without human assistance, even if they are present in the landscape (Öckinger et al. 2018).

In summary, ample evidence exists to indicate that responses related to enhancing the wider landscape positively contribute towards improving pollinator communities. The spatial and temporal scales of the interventions and the roles and coordination of different actors in a landscape context are a critical consideration to ensure optimal effectiveness of measures deployed. While further evidence is required to understand exactly where and in what locations these interventions would be most effective, Kleijn et al.'s (THIS ISSUE) suggestion to incorporate key performance indicators that can be quantified easily 
over large areas would be a practical means of monitoring, evaluating and assessing conservation effectiveness of interventions at the landscape scale.

\subsection{Regulation and Management of Pesticides}

Responses assessed:

- Raise standards of pesticide and GMO risk assessment

- Practices to reduce pesticide drift and exposure

- Reduce pesticide use

- Promote Integrated Pest Management (IPM)

Pesticides are used to control injurious pests in agricultural systems and include insecticides, herbicides and fungicides. Conventional synthetic pesticides have become a key input upon which farmers rely in modern intensive agriculture. While underpinning high yields, they have led to widespread unintended environmental consequences (Wilson and Tisdell, 2001). The negative impacts of pesticides, and particularly insecticides, on pollinators has been subject to intensive research in recent years (Sponsler et al. 2019) with a multitude of effects on pollinators reported including on behaviour, reproduction, longevity (Godfray et al. 2014) and resulting pollination services (Stanley et al. 2015). Reducing pesticide use will ultimately require coordinated action of multiple actors from many sectors (Sponsler et al. 2019) and given the negative environmental implications of over reliance on pesticide, it is a priority for society as a whole. However, some small scale actions can be effective and we conclude from our assessment that they will require direct action from only a few actors (e.g. farmers) with support from one or two sectors (e.g. Agri-food, Policy) (Table 2).

Mitigating the negative impacts of pesticides on pollinators is a priority and requires multiple actions that go beyond simply banning their use, given their utility in multiple contexts. Responses include 'Raising standards of risk assessments for pesticides and GMO', which are required before any product can go to market. With regards to impacts on pollinators, assessments have tended to focus on effects on a limited number of pollinator species, including the western honey bee Apis mellifera, which recent studies have shown is relatively less sensitive to insecticides than other pollinators (Rundlöf et al. 2015). To understand true risks, assessments need to consider sub-lethal effects on a wider set of pollinator 
species over the longer term and in the context of field realistic doses (Stoner, 2016; Thompson and Hunt, 1999; IPBES 2016a; Mancini et al. 2020 THIS ISSUE). Also, the wider ecological implications of their use need to be considered, for example the loss of pollinator forage plants following employment of GMO 'herbicide ready' crops and subsequent application reducing arable weed availability (Bohan et al. 2005).

Recent estimates of the full costs of bringing a single active ingredient from discovery to market are, on average, U.S. \$286 million and take over 11 years (McDougall, 2016). Effective risk assessment requires coordinated action from multiple sectors including policy makers who set risk assessment standards and agrochemical companies who develop pesticide products or GMO crops lines. Following reassessment, the European Food Safety Authority (EFSA) considered the widely used neonicotinoid family of insecticides to pose an unacceptable harm to bees, resulting in a ban on their use in outdoor crops across Member States. Acting through policy at a continental scale will restrict pesticide use. The extent that this will deliver benefits for pollinators remains to be seen, however, given the potential time lags for measurable effects on pollinator populations to emerge (Woodcock et al. 2016. Mancini et al 2020 THIS ISSUE) and the unknown impacts of alternative chemicals marketed and used (Zhang et al. 2017). Including appropriate risk assessment procedures that considered factors raised as presenting unacceptable risks in the EFSA 2018 report would have avoided the need for a retrospective restriction. This requires coordinated action between multiple actors and sectors, allowing science to inform policy and industry in order to shape risk assessment, and such processes must be in place well before active ingredients may be released to market (Table 2).

Beyond wide scale restrictions on the availability of pesticides, 'Reducing pesticide use' by encouraging alternatives and utilising new technologies or application approaches 'to reduce pesticide drift and exposure' could reduce pesticide pressures on pollinators at smaller spatial scales. These practices can be implemented by individual farmers on individual farms and deliver several short-term benefits. For example, the negative effects of pesticides on pollinators at the time of application (Brittain et al. 2010) can be mitigated through the establishment of buffer zones. These comprise adjacent riparian zones and field edges known to be key foraging and nesting habitats for pollinators and so minimise contact with treated crops (Cole et al. 2015; Garratt et al. 2017; Lagerlöf et al. 1992). This will also avoid unintentional pesticide drift and leaching into semi-natural areas where pollinators can become exposed (Botías et al. 2016; Dover et al. 1990). Given the wide foraging range of many pollinating insects (Doyle et al. 2020; Greenleaf et al. 2007), farm and field scale approaches to reduce pesticide use cannot fully 
mitigate the risks. Exposure will ultimately result from pollinator foraging on other crops and wild plants within the wider landscape (Brittain et al. 2010; McArt et al. 2017). Maintaining a high proportion of semi-natural habitat in the landscape may mitigate further the effects of pesticide and promote the recovery of pollinator populations (Park et al. 2015). To be most effective, practices to reduce pesticide application need to be implemented beyond individual fields and take into account risk of exposure across the whole landscape [see section 3.2].

Actions to reduce risks from pesticides are needed at multiple spatial and temporal scales and this will require collaboration between multiple actors within several sectors (policy, farmers and manufacturers). To ensure products that do not pose an unacceptable risk to pollinators are available, risk assessment needs to be fit for purpose requiring coordinated inputs from researchers, policy makers and industry (e.g. chemical manufacturers, growers, agronomists) over a sustained period to avoid outcomes such as the retrospective restriction on neonicotinoids based on evidence of environmental harm (IPBES 2016a; van Lexmond et al. 2015). This has presented many challenges, particularly for farmers, in adapting management practice at short notice. By contrast, local scale responses to reduce application and drift of pesticides, as well as employment of Integrated Pest Management (IPM) (Vanbergen et al. 2020 THIS ISSUE) [see section 3.5], undoubtedly deliver benefits to pollinators by avoiding direct exposure to pesticides. This requires action from only a few sectors, namely the agri-food sector, with support from policy.

\subsection{Managed Pollinators}

Responses assessed:

- Manage diseases and trade in managed pollinators

- Improve managed bee husbandry

- Develop alternative managed pollinators

- Quantify the benefits of managed pollinators

- Develop markets for alternative managed pollinators

In many global systems, a number of managed insects, such as the European honeybee (Apis mellifera), bumblebees (Bombus spp.) and stingless bees (Meliponinina spp.) are used to provide large scale 
pollination services and can act to supplement or provide insurance against wild pollinator declines. While global use of managed pollinators has increased, localized declines due to disease can significantly disrupt crop systems that rely upon them (Aizen et al. 2019, 2020 THIS VOLUME). The IPBES report recommends a number of responses around the theme of managed pollinators: managing diseases and trade, improving husbandry, developing alternative managed pollinators and markets for them and properly quantifying the benefits to crops. Of the scales considered, spatial (e.g. national), actor (e.g. beekeeper) and sectoral (e.g. beekeeping) are the most important to managed pollinators, although a degree of long-term planning is also necessary for many.

Although honeybees are often managed exclusively for the hive products, such as honey, wax and propolis, demands for crop pollination from farmers have driven their widespread use as crop pollinators (Rollin and Garibaldi, 2019; Aizen et al. 2020 THIS VOLUME). Much of the global use of honeybees as pollinators is at small spatial scales, with local beekeepers providing services to local farmers in exchange for payment or simply the right to access high densities of flowers (e.g. Breeze et al. 2019). However, in some countries, large commercial beekeepers provide contracted pollination service work to farmers, often travelling significant distances to do so (Lee et al. 2018). Managed pollination on the scale seen in the USA is critically dependent upon the continued demands of high-intensity almond production in California that creates sustained income opportunities for migratory beekeepers who otherwise subsist on lower paid pollination contracts and honey (Lee et al. 2018). Such intensive pollination markets are unlikely to arise elsewhere due to the lack of such concentrated and reliable demand for pollination services and international barriers such as differences in regulations regarding honeybee movement and language differences (Breeze et al. 2019). As such, many issues of bee health are a product of national spatial scales, driven by activity between different actors (growers and beekeepers) within the agri-food sector.

Despite their high numbers, honeybees are not efficient pollinators of many crops or in every crop system (Bosch and Kemp, 2002; Garibaldi et al. 2013). Subsequent demand for more reliable alternatives has driven the domestication of a number of alternative managed pollinators. Most notably, the commercial production of colonies of the bumblebee Bombus terrestris arose primarily from market demands for a reliable source of tomato pollination (Banda and Paxton, 1991; Velthuis and van Doorn, 2006). Despite limited evidence of the densities required for effective pollination, the use of $B$. terrestris and other alternative taxa has expanded globally and through innovation to other crop systems, such as soft fruits in semi-enclosed systems. However, this global trade of $B$. terrestris has created issues of 
potential biological invasions (Aizen et al. 2020 THIS VOLUME; Vanbergen et al. 2018), resulting in many countries placing restrictions on the import of managed bumblebees and ultimately domesticating other local species such as B. hypocrita in Japan (Takeuchi et al. 2018) to fulfil their role as managed pollinators in local farming. Other pollinators have been bred for more specialized systems such as the alfalfa leafcutter bee (Megachile rotundata), initially to facilitate alfalfa production for livestock fodder (Pitts-Singer and Cane, 2011), but it has since proven to be efficient in a range of other crop plants (Richards, 2016, 2020). Commercial rearing of a species typically takes around a decade (Bosch and Kemp, 2002) and requires corporation between actors in farming, beekeeping and research primarily working in the agri-food sector. Further commercial rearing of species is likely to continue to be marketdriven, relying on demands from growers for a cheaper, more effective alternative to honeybees, particularly in countries where the managed pollinator market is insufficient to sustain large beekeeping stocks.

To date, control on the use of managed pollinators by local or national government has been relatively localized. For example, the UK restricts bumblebee imports to native subspecies of $B$. terrestris (Natural England, 2020) while Japan has banned B. terrestris imports entirely in response to feral populations causing severe resource pressures on native bumblebee species (Ministry of the Environment, 2004). Effective regulation of the movement of managed pollinators is likely to require multiple actors (policymakers, breeders and farmers) and sectors (private enterprises and governments) across multiple countries (Aizen et al. 2018). Failure to act across large spatial scales has led to the global spread of the parasitic mite Varroa destructor, a leading driver of honeybee colony mortality globally (Vanbergen et al. 2018). Currently Australia is the only region unaffected by the mite thanks to its strict biosecurity policy (Philips, 2020; Australian Government, 2020). However, some countries such as the USA have since stepped up biosecurity to prevent the spread of further parasites such as Tropilaelaps sp. into their own borders (Steinhauer et al. 2018). Furthermore, there is growing evidence that the mass transit of managed pollinators creates additional pressures on wild pollinator populations through resource competition, disease and gene transfer (Aizen et al. THIS VOLUME; Graystock et al. 2016; Lindström et al. 2016).

Managed honeybee colonies can number several thousand individuals and have lifespans of several years, making commutable diseases and parasites a significant long-term pressure upon their populations. At smaller social and spatial scales, beekeeping associations and communities may also play a role in improving bee husbandry through informal knowledge exchange on best practices (Bedford and 
Neville, 2016). However, the extent of such knowledge exchange is unclear and may be regarded by some actors as less valuable than primary research due to limited scientific rigor (Maderson and WynneJones, 2016). Efforts to control honeybee pests and diseases at larger spatial scales are typically policy oriented, driven by government or by local or national beekeeping organizations. In particular, several countries have national bee health programmes designed to monitor and combat outbreaks of serious pests and diseases, for example, the European Union provides centralized funds for a range of bee health activities within Member States (European Commission, 2013). This lacks central co-ordination and has not been substantially updated in recent years. These programs are often long term but require continued updates to adapt to the increasing spread of pests and diseases. Although there have been recommendations for international approaches to improve bee husbandry and disease management practices (Jacques et al. 2017), to date, such international collaboration is limited. The most prominent example is the, COLOSS (Prevention of Honeybee Colony Losses) research network, spanning 95 countries which manages much of the international monitoring of honeybee colony losses and provides a platform for exchanging data and information but not prescriptive action (COLOSS, 2020).

The available evidence highlights the need to consider responses to pressures on managed pollinators at multiple scales. Spatial scales vary tremendously from local demands for innovative managed pollinators and improved bee husbandry to international efforts to support bee health. Multi-actor collaborations across agri-food sector actors and policy are consistently important for managed pollinator interventions. However, despite a substantial body of research on specific practices, knowledge on how the links between different actors (consumers, growers and managed pollinator suppliers) can affect the effectiveness of these measures remains lacking.

\subsection{Diversifying Farming Systems}

Responses assessed:

- Managing blossoming of mass-flowering crops

- Change management of grasslands

- Plant breeding to reduce reliance on biotic pollination

- Support diversified farming

- Promote no-till farming 
- Adapt farming to climate change

- Promote Integrated Pest Management (IPM)

Agricultural expansion and intensification are key drivers of biodiversity loss and extinctions at local, regional and global scales (Newbold et al. 2016) with impacts on the organisms that provide services underpinning crop production itself including pollination (Tscharntke et al. 2012). The IPBES report highlights a number of responses around the theme of 'Supporting diversified farming' that could mitigate the effects of conventional agricultural practices on pollinators. Such diversification can be at the whole system level, including promoting alternative philosophies that incorporate practices which can benefit pollinators (e.g. IPM, no-till farming, changed management of grasslands) including ecological intensification, organic farming and agro-ecological farming (Garibaldi et al. 2017; Vanbergen et al. 2020 THIS ISSUE). Diversification of farming can also be achieved by moderating how many and which crops are grown in the landscape. This can be realized either through increasing the diversity of crops produced at local, regional and national scales (Aizen et al. 2019) or by combining arable and livestock through mixed farming, which can provide grassland habitats beneficial for pollinators, if appropriately managed (Orford et al. 2016). Diversity can also be introduced to the farmed environment by incorporating crops with particular traits such as 'plant breeding to reduce reliance on biotic pollination' or moderating planting regimes to allow for 'managing blossoming of mass-flowering crops', which could improve the availability of pollen and nectar in the landscape. The spatial and temporal scales, actors and sectors involved vary depending on responses, from short-term field scale interventions such as reduced tillage to landscape coordination of flowering crops and long-term crop breeding initiatives (Table 2).

Increasing crop diversity requires pollinator communities to contain functionally diverse species to ensure optimal pollination of different crops (Garibaldi et al. 2015; Garratt et al. 2014; Winfree et al. 2018). At the same time growing different crops can provide contrasting nesting and forage resources and deliver benefits for pollinators at the field (Montoya et al. 2020; Pereira et al. 2015) and farm scale (Guzman et al. 2019). Such responses could be implemented by individual farmers and deliver benefits in the short term. However, crop diversity alone may not deliver all necessary resources for pollinators, and the presence of non-crop areas as source habitat within the wider landscape is still critical (Hass et al. 2018; Kennedy et al. 2013) as discussed in Section 3.2. To date however, crop diversification at national, regional and global scales has failed to track increase demands in pollination services (Aizen et al. 2019). 
Diversifying farming can also be achieved through a suite of management options or approaches ranging from optimizing management, substituting harmful practices or redesigning the farm system to make better use of nature-based agricultural solutions (Vanbergen et al. THIS VOLUME). Ecological intensification, organic farming and IPM approaches can benefit pollinators by providing additional forage and reducing exposure to agrochemicals (Biddinger and Rajotte, 2015; Kovács-Hostyánszki et al. 2017; Tuck et al. 2014). Even when organic farms and fields are embedded in conventional agricultural landscapes, they have been shown to increase pollinator diversity (Holzschuh et al. 2008). Promoting and supporting system level changes to farming practice and agricultural systems is challenging (Vanbergen et al THIS VOLUME) and has not always been successful, as is the case for IPM (Alwang et al. 2019; Creissen et al. 2019). It requires engagement of multiple actors (e.g. farmers, researchers, industry, politicians) from several sectors and motivation derived from wider social groups and markets [see section 3.6].

Plant breeding to reduce our reliance on pollinators could minimise the vulnerability of food production systems to pollinator decline (Knapp et al. 2017). However, making crops independent of pollinators could forsake the benefits to crop yield and quality and disease resilience which outcrossing delivers (Klatt et al. 2014). In any case successfully breeding new crops by conventional means will take many years and requires the support of plant breeders and the agri-food sector, although gene editing technology may provide a solution (see Vanbergen et al. 2020 THIS ISSUE). Breeding crop varieties that provide an improved floral resource for pollinators (e.g. in the form of increased nectar or pollen availability) could help protect pollinator populations in agricultural landscapes (Prasifka et al. 2018), particularly considering the role mass-flowering crops can play in benefiting pollinators (Westphal et al. 2003).

Diversifying farming systems can be achieved through action at multiple spatial and temporal scales, from changes to field scale management practices in the short term, to supporting widespread shifts of whole farming approaches in the longer-term. It is clear that benefits to pollinators through increased resource availability can be achieved even by relatively small-scale actions e.g. diversifying crops within fields or rotations. However, larger scale and longer-term changes to farming approaches will require action from multiple actors beyond farmers, support from beyond the agri-food sector (e.g. researchers and policy makers) and will likely be driven by pressure from beyond the immediate peer group (e.g. general public). 


\subsection{Improving Markets}

Responses assessed:

- Reward farmers for pollinator-friendly practices

- Support product certification and livelihood approaches

- Establish payment for pollination services schemes

- Support market-based solutions and innovations

Pollination services are a key production input to the global agri-food sector, with an estimated economic value of hundreds of billions of US\$ globally (IPBES, 2016a). Furthermore, many of the pressures affecting pollinators are driven by economic activities, such as land use and management changes to accommodate demand for large scale, low cost food. As such, market-oriented efforts to support a transition to a more sustainable food system have often been proposed as a means to alleviate pollinator declines. In addition to direct rewards for pollinator-friendly practices, the IPBES (2016a) report highlights the potential of product certification, livelihoods approaches, payments for ecosystem services and market-oriented solutions as means to potentially support pollinator conservation within markets.

To date, most relevant market-oriented innovations are label-based schemes, operating at a national or international level, that offer individual participating farmers a premium for using lower chemical inputs (organic farming) or maintaining diverse habitats or management practices (e.g. LEAF, 2020; PicoMendoza et al. 2020) [see section 3.5]. These schemes typically arise in response to consumer demands for sustainable products (Edwards and Laurance, 2012) but are implemented through a co-operation between growers and particular businesses. Although such schemes can be effective at supporting pollinator populations (e.g. shade coffee - Iverson et al. 2019; organic farming - Kennedy et al. 2013), they are almost never directly targeted at improving pollination services or populations of key pollinators. Furthermore, their focus is limited in scale to individual farmers to supplying a premium product rather than transforming the wider food system. Expanding such schemes is possible and may even be inevitable, if consumer demand is high enough, but careful planning is necessary to ensure that environmental gains do not come at the expense of food availability (Reganold and Wachter, 2016) due to lower overall productivity or higher prices (Seufert et al. 2012). 
A broader approach to incentivizing management has come from national and regional government sponsored agri-environment schemes, developed in response to societal concerns over the impact of farming on the environment. These schemes (e.g. Batáry et al. 2015 for an EU review) directly pay growers for undertaking management that benefits biodiversity. This affects markets indirectly by reducing the availability of land for food production at a national scale and compensating farmers for otherwise risky and unproductive measures. However, although measures such as crop diversification and planting flower rich field margins can be effective in supporting pollinators [see section 3.1], many are not directly targeted towards supporting pollinators and where they are (e.g. flower rich field margins), they may not be suitable for particular local species assemblages (Wood et al. 2015). Many of the most effective options are also among the most expensive (Breeze et al. 2014), increasing the initial capital requirements for such measures and reducing the value of payments made (Blaauw and Isaacs, 2014). Such payments often cannot simply be increased to add greater incentives, due to international governance on trade (WTO, 1995). Finally, these incentives remain mostly focused on encouraging individual farmers to undertake action in specific fields rather than fostering a larger scale more collaborative approach necessary for maximum benefit (Kleijn et al. 2019).

The most market-oriented efforts to supporting pollination services are payments for ecosystem services (PES) schemes. These are dual or multi-actor schemes where stakeholders (usually a business in collaboration with an NGO or government) directly pay landowners for providing a particular ecosystem service. Effective local, national and international PES schemes have been developed for services such as water quality (Martin-Ortega et al. 2013) and carbon capture (Balvanera et al. 2012) but not for pollination at present. However, effective PES schemes typically require payments by results, which in the case of pollination requires dedicated methods of assessment (Garratt et al. 2019) and can vary due to interactions between the plant and other growing conditions such as soil quality (Bishop et al. 2020). Furthermore, because pollination is a non-excludable service (Fisher et al. 2009), some potential buyers may "free-ride" the system and receive the benefits without payment. As the beneficiaries and suppliers of pollination services are likely to be farmers, PES schemes are most likely to be effective as contracts between different farmers within the same landscape, with those who do not directly benefit from pollination services receiving payments from those farmers who do.

The effectiveness of each of these market-oriented initiatives could potentially be demonstrated by evaluating the economic benefits of such measures over a longer time span than simply the year in which they are planted. For example, Blaauw and Isaacs (2014) demonstrated that flower rich field 
margins increased blueberry yields sufficiently to become profitable in 3-5 years depending on market price and subsidies. Under such circumstances, farmers may be more inclined to partake in pollinator conservation with or without a degree of external investment, simply to ensure their own long-term profitability (Kleijn et al. 2019). To date however, such applied economic evidence is relatively scare (Breeze et al. 2016).

In summary, existing market-oriented efforts that benefit pollinators are consistently focused on supporting action at small (field and farm) spatial scales but are driven by multi-actor interactions between different sectors - growers, retailers and policy. Many of these efforts are relatively new, spatially limited or poorly studied. As such, there is a lack of key evidence on their cost-effectiveness, which will be critical to facilitating their wider adoption by farmers and other market actors.

\subsection{Knowledge Generation and Exchange}

Responses assessed:

- Inform farmers about pollination requirements

- Collaborative approaches to landscape management

- Translate pollinator research into agricultural practices

- Traditional and knowledge co-production for habitat management

- Support biocultural diversity conservation approaches

- Support knowledge co-production and exchange

- Strengthening Indigenous and Local Knowledge

- Education and outreach programmes

- Monitor and evaluate pollination on farms

- Monitor pollinators

- Increase taxonomic expertise

Research on pollinator conservation and the efficacy of specific interventions to enhance pollinator communities as well as pollination has increased substantially in the last few decades; however, the knowledge gained so far has been mainly fragmented and difficult to collate and combine, making it 
difficult to integrate and synthesise (Bartomeus and Dicks, 2019). Knowledge exchange and dissemination is key to ensuring that evidence is translated into practical impact, and the list of interventions above, while illustrative, is not exhaustive in terms of how this could be achieved.

Most of the interventions outlined above need no further detailed explanation, but 'biocultural diversity', requires explanation. Biocultural diversity refers to the variety of people-nature interlinkages that have developed over time in specific ecosystems. Biocultural approaches to conservation incorporate customary governance systems of indigenous peoples and local communities (IPLCS) across the world, their spiritual and cultural values and explicitly build on conservation practices inherent in sustaining IPLC livelihoods (Hill et al. 2019). These authors identified several biocultural approaches to pollinator conservation across the world. The strongest approaches incorporate policies that recognize customary tenure over traditional lands, strengthen indigenous and community-conserved areas, promote heritage listing and support diversified farming systems within a food sovereignty approach delivering mutual benefits for pollinators and people. They also highlighted that these responses operate across various spatio-temporal scales. For example, biocultural interactions in the Agave Landscape in Mexico have been in place since the 16th century to produce tequila spirit, with knowledge transfer transcending several generations over an extensive landscape. Such long-term biocultural approaches may also be limited to smaller spatial scales such as within single tribes of honey hunters in Ethiopia, Cameroon and Nepal.

An inter-disciplinary, cross-sectoral approach is reflected in almost all the options highlighted in this section; many are influenced by social scales in particular peer groups, local communities and wider society (Table 2). For instance, if collaborative approaches to landscape management are to be successful in enhancing pollinator communities, they need to incorporate various other components including translating research into practice, informing farmers about pollination requirements, monitoring and evaluation, as well as supporting knowledge co-production and exchange. None of these can be successful unless they are multi-actor responses that work across landscapes and bring together various sectors including policy, business, NGOs, researchers as well as the general public and require buy in from the community and society. For instance, The Xerces Society's Bee Better Certified scheme states, "The Bee Better production standards are science-based and field-tested, guaranteeing that the actions farmers take actually improve pollinator well-being. Third-party verification ensures that the certification process is transparent and trustworthy", providing an example of cross-sectoral approach 
relevant to agri-food business as well as consumers (Xerxes Society, 2020b). The Landscapes for wild pollinators initiative [see section 3.2) is also an example of a cross-sectoral approach to pollinator conservation.

Many international, regional and national plans involve education institutions such as schools and some include faith communities too. Faith and local communities have an important role in ensuring that traditional, indigenous and local knowledge is utilised for habitat management approaches. For instance, the Ethiopian Orthodox Tewahido Churches are situated within forests, which are both a religious and a biodiversity sanctuary, providing the local community with ecosystem services such as fresh water, shade, honey, pollinators, and spiritual value (Cardelus et al. 2012). Local indigenous knowledge is being utilised for the recovery of stingless beekeeping for rural livelihoods, in several areas across the world including tropical America, India, Africa and temperate South America (Hill et al. 2019; Rehel et al. 2009). These knowledge exchange and knowledge transfer options while limited to the local landscape of a specific community, may transcend multiple generations and are heavily influenced by the social aspects of peer groups and local communities.

A much shorter timeline towards pollinator conservation success could be achieved through improved and increased education and outreach programs to distribute knowledge across wider spatial scales in shorter time. There already exists a suite of materials developed by various organisations across the world to disseminate information to growers, land managers, general public as well as school children (FAO, 2013; lowa State University, 2013; U.S. Fish and Wildlife Service, 2019). Local councils and national governments have also instituted awards for primary and secondary schools that establish pollinator conservation scheme in their local environment, such as the Bees Needs Champions Awards (DEFRA, 2017). The United Nations World Bee Day, celebrated on the $20^{\text {th }}$ of May, and National insect weeks that are celebrated annually also improve awareness and enable wider broadcasting of the need for pollinator conservation and bring-together local communities and the wider society.

Ecologically intensive (EI) approaches to farming (Vanbergen et al. THIS VOLUME) can help pollinators, yet despite some evidence proving the benefits to crop yields (Blaauw and Isaacs, 2014; Pywell et al. 2015; Garibaldi et al. 2019), there has often been a lack of widespread uptake. This has been blamed, at least in part, on a failure to utilise appropriate knowledge pathways and mechanisms (Wyckhuys et al. 2018) or consider the social and economic contexts that guide farmer behaviour (Caron et al. 2014; 
Rusere et al. 2019). Limited adoption of integrated pest management (IPM) [see section 3.3] has also been attributed to a lack of farmer awareness and knowledge, perceptions of low profitability, and risk and uncertainty, particularly in smallholder farming systems (Alwang et al. 2019). Engaging end-user (farmers in the case of El and IPM) at the knowledge generation stage and considering factors such as yield and profit and spatio-temporal scales relevant to farmers, will likely improve uptake when effective interventions are developed (Kleijn et al. 2019).

Perhaps the most challenging aspect of knowledge generation and exchange is monitoring and evaluating the success of such measures. There have been some long-term initiatives like the Vigie Nature in France (Vigie Nature, 2020) which was initiated over 20 years ago as a participatory science programme aimed at beginners to experts. The UK Pollinator Monitoring Scheme (PoMS, 2020) established in 2018 aims to systematically collect data and build on a wealth of existing citizen science expertise, which includes both amateur natural historian and academic researchers. The EU Pollinators Initiative (European Commission, 2020) is also developing a regional monitoring scheme, one of the key challenges is the availability of taxonomic experts to accurately identify the pollinator species in different locations. Initiatives such as the EU COST Action Scheme SUPER-B (SUPER-B, 2018) provided training for early career entomologists to hone their taxonomic identification skills through a series of workshops but such opportunities remain few and confined to certain geographical areas. Facilitating the transfer of knowledge from experts to the next generations remains a crucial aspect of guaranteeing the future success of the interventions discussed within this theme.

\subsection{High Level Pollination Initiatives and Strategies}

Responses assessed:

- Support high-level pollination initiatives and strategies

The last decade or so has seen the emergence of several global and many national initiatives for pollinators; by definition these cover the national and global spatial scales. A common element running through all of them is the inclusion of multiple actors and multiple sectors, with action plans and strategies operating over the longer term (Table 2). 
The UN Intergovernmental science-policy Platform on Biodiversity and Ecosystem Services (IPBES, www.IPBES.net) undertook the first global assessment of evidence on the status, trends, values, and drivers of pollinators and pollination services, as well as the adaptation and mitigation options (IPBES, 2016a, b). It addressed these across spatial and temporal scales and included responses and approaches from single and multiple actors from across all sectors. While the IPBES reports did not provide specific recommendations, they did provide policy relevant information and options, which fed into or stimulated many global (e.g. Convention on Biological Diversity, CBD (CBD, 2020), Food and Agriculture Organisation International Pollinator Initiative, FAO IPI (FAO, 2020)), regional (e.g. EU Pollinators Initiative, EPI, COM, 2018) and national initiatives and strategies (e.g. the 28 members of Promote Pollinators (Promote Pollinators, 2020), formerly Coalition of the Willing on Pollinators).

The CBD Conference of Parties Decision XIII/15 (CBD, 2016), endorsed by all signatory governments and set out a number of actions to protect pollinators and encouraged their adoption at the national and global scales (196 governments) and involving multiple actors (e.g. farmers, beekeepers, pesticide manufacturers, indigenous peoples, policy makers, researchers, academics) drawn from multiple sectors. The actions include many of the responses, and scale relevant aspects, described in the previous seven themes, but while the action plans for most of these initiatives are for 5 or 10 years (e.g. EPI), they often have visions going well beyond this up to 2050 (e.g. FAO IPI). National plans and strategies are structured in similar ways taking into account multiple spatial, temporal, actor, social and sectoral scales (e.g. the 28 countries of Promote Pollinators). There are other initiatives with different scale dimensions, such as the NGO International Union for Conservation of Nature, IUCN (IUCN, 2020), which has conducted pollinator threat assessments at the global (mammals only), regional (European bees and butterflies), and national scales (IPBES, 2016a); these are partnerships between the IUCN, researchers, citizen scientists and other experts such as amateur entomologists.

A common driver of all the international and national initiatives is the increased awareness and call to action from the public (as well as scientists, businesses and NGOs). No formal assessments of how the different dimensions of scale influence the effectiveness of high level strategies, initiatives and responses aiming to conserve pollinators and pollination through exist to our knowledge. The fact that conserving pollinators is a complex multi-faceted challenge involving all sectors of society means that large scale, long-term multi-actor approaches are deemed essential for addressing these challenges (Gill et al. 2016). 


\section{CONCLUSION AND OUTLOOK}

Our assessment of the relative importance of scales, and levels within scale categories, for the effectiveness of interventions revealed a heterogeneous spread (Table 2). However, there were several emergent patterns highlighted through our exploration of the eight themes. Overall, we found that ecological interventions will only be effective when targeted over the right spatial scales over a sufficient period of time and involve all relevant social and sectoral groups and actors. While the effective scales may vary between individual responses, the common denominator for success is the identification of the right actors and sectors to enable optimal implementation across those spatial and time scales. Further, in all cases the motivations and support for interventions is often derived from groups beyond the actors themselves and so engagement and awareness raising is needed. In order to achieve effective, sustainable management, we need to both recognize different scales and consider how they interact to affect decisions.

Many of the motivations driving the implementation of interventions for pollinator conservation or pollination services management stem from complex interactions between human needs and environmental goals that are rarely the focus of primary research. However, the available evidence highlights the need to consider interventions at multiple scales, although knowledge on what exact scales at which specific responses should be implemented to effectively support pollinators remains lacking. We therefore recommend that when planning interventions an early assessment of the most critical spatial, temporal, actor, social and sector scales is made in order to provide the best preconditions for effective implementation and probability of success. An assessment of scale requirements to inform on targeting the correct spatial and temporal scales and involving and engaging the appropriate set of actors and sectors, is likely to constitute a relatively small cost in resources. This initial investment is likely to be hugely offset through a substantial increase in the effectiveness of interventions and the benefits they provide.

In this paper, we followed a largely exploratory approach, with a small number of experts rapidly assessing the importance scale. While this highlighted several general trends, we recognize there is a major opportunity to build on this using a much more rigorous Delphi process (e.g. Mukherjee et al. 2015). We recommend that a larger panel of experts is used (e.g. 20-30 individuals) with a greater 
breadth of knowledge and drawn from the academic, policy and practitioner community, with the composition tailored to match the aim of the assessment. Such an approach, for instance, has worked well for the assessment of agri-environment-type measures to support pollinators in EU agriculture (Cole et al. 2020). Future approaches could take a global perspective and explore how scale and effectiveness relationship change regionally, or they could be tightly focused and look at a small number of interventions in specific contexts (e.g. on farm habitat management in a particular country) and used to fine tune the implementation of management practices.

To deliver maximum benefit for pollinators and pollination, implementation of multiple responses simultaneously will be required, including those that mitigate risks to pollinators, maximise the ecosystem services they provide, transform landscapes to support populations, and raise awareness and promote engagement with pollinators and pollination. Coordination of such an array of approaches will likely fall to large scale initiative and strategies and be implemented across large spatial scales and long timeframes. Such initiatives will shape the landscapes of the future by integrating activities in the urban, agricultural, and natural environments and engaging the many sectors and actors necessary to do this. Ultimately these landscapes will be made up of a combination of the many small-scale targeted responses and larger scale activities to create multifunctional landscapes that promote and sustain pollinator populations whilst simultaneously meeting the needs of people, agriculture, and food security.

\section{References}

Aizen, M. A., Aguiar, S., Biesmeijer, J. C., Garibaldi, L. A., Inouye, D. W., Jung, C., Martins, D. J., Medel, R., Morales, C. L., Ngo, H., Pauw, A., Paxton, R. J., Sáez, A., Seymour, C. L., 2019. Global agricultural productivity is threatened by increasing pollinator dependence without a parallel increase in crop diversification. Glob. Chang. Biol. 25, 3516-3527.

Aizen, M. A., Smith-Ramirez, C., Morales, C. L., Vieli, L., Saez, A., Barahona-Segovia, R. M., Arbetman, M. P., Montalva, J., Garibaldi, L. A., Inouye, D. W., Harder, L. D., 2018. Coordinated species importation policies are needed to reduce serious invasions globally: The case of alien bumblebees in South America. J. Appl. Ecol. 56, 100-106.

Alwang, J., Norton, G., Larochelle, C., 2019. Obstacles to Widespread Diffusion of IPM in Developing Countries: Lessons From the Field. J. Integr. Pest Manag. 10, 1-8.

Aronson, M. F. J., Lepczyk, C. A., Evans, K. L., Goddard, M. A., Lerman, S. B., Maclvor, J. S., Nilon, C. H., Vargo, T., 2017. Biodiversity in the city: key challenges for urban green space management. Front. 
Ecol. Environ. 15, 189-196.

Australian Government., 2020. Biosecurity Act 2015, Compilation No. 8 https://www.legislation.gov.au/Details/C2020C00127.

Baldock, K. C. R., 2020. Opportunites and threats for pollinator conservation in global towns and cities. Curr. Opin. Insect. Sci. 38, 63-71.

Baldock, K. C. R., Belfin, B., Ahjokoski, T., Gardiner, J., Rogers, L., Steer, M., Whitehouse, A., Pattison, S., Birkin, M., Barsby, T., 2015. Greater Bristol Pollinator Strategy 2015-2020. https://www.bristol.ac.uk/media-library/sites/biology/documents/GrBrisPollStrategy.pdf.

Baldock, K. C. R., Goddard, M. A., Hicks, D. M., Kunin, W. E., Mitschunas, N., Morse, H., Osgathorpe, L. M., Potts, S. G., Robertson, K. M., Scott, A. V., Staniczenko, P. P. A., Stone, G. N., Vaughan, I. P., Memmott, J., 2019. A systems approach reveals urban pollinator hotspots and conservation opportunities. Nat. Ecol. Evol. 3, 363-373.

Baldock, K. C. R., Goddard, M. A., Hicks, D. M., Kunin, W. E., Mitschunas, N., Osgathorpe, L. M., Potts, S. G., Robertson, K. M., Scott, A. V., Stone, G. N., Vaughan, I. P., Memmott, J., 2015. Where is the UK's pollinator biodiversity? The importance of urban areas for flower-visiting insects. Proc. R. Soc. B Biol. Sci. 282, (1803).

Balvanera, P., Uriarte, M., Almeida-Leñero, L., Altesor, A., DeClerck, F., Gardner, T., Hall, J., Lara, A., Laterra, P., Peña-Claros, M., Silva Matos, D. M., Vogl, A. L., Romero-Duque, L. P., Arreola, L. F., CaroBorrero, Á. P., Gallego, F., Jain, M., Little, C., de Oliveira Xavier, R., Paruelo, J. M., Peinado, J. E., Poorter, L., Ascarrunz, N., Correa, F., Cunha-Santino, M. B., Hernández-Sánchez, A. P., Vallejos, M., 2012. Ecosystem services research in Latin America: The state of the art. Ecosyst. Serv. 2, 56-70.

Banda H. J., Paxton R., 1991. Pollination of Greenhouse Tomatoes by Bees. Acta Hortic 288, 194-198.

Bartomeus, I., Dicks, L. V., 2019. The need for coordinated transdisciplinary research infrastructures for pollinator conservation and crop pollination resilience. Environ. Res. Lett. 14, 045017.

Batáry, P., Dicks, L. V., Kleijn, D., Sutherland, W. J., 2015. The role of agri-environment schemes in conservation and environmental management. Conserv. Biol. 29, 1006-1016.

Baude, M., Kunin, W. E., Boatman, N. D., Conyers, S., Davies, N., Gillespie, M. A. K., Morton, R. D., Smart, S. M., Memmott, J., 2016. Historical nectar assessment reveals the fall and rise of floral resources in Britain. Nature 530, 85-88.

Bedford, D., Neville, L., 2016. Knowledge Sharing and Valuation in Beekeeping Communities: A Linguistic Analysis; Proceedings of the 13th International Conference on Intellectual Capital Knowledge Management \& Organizational Learning, Pages: 18-30.

Biddinger, D. J., Rajotte, E. G., 2015. Integrated pest and pollinator management - adding a new dimension to an accepted paradigm. Curr. Opin. Insect Sci. 10, 204-209.

Bishop, J., Garratt, M. P. D., Breeze, T. D., 2020. Yield benefits of additional pollination to faba bean vary with cultivar, scale, yield parameter and experimental method. Sci. Rep. 10, 1-11.

Blaauw, B. R., Isaacs, R., 2014. Flower plantings increase wild bee abundance and the pollination services 
provided to a pollination-dependent crop. J. Appl. Ecol. 51, 890-898.

Bohan, D. A., Boffey, C. W. H., Brooks, D. R., Clark, S. J., Dewar, A. M., Firbank, L. G., Haughton, A. J., Hawes, C., Heard, M. S., May, M. J., Osborne, J. L., Perry, J. N., Rothery, P., Roy, D. B., Scott, R. J., Squire, G. R., Woiwod, I. P., Champion, G. T., 2005. Effects on weed and invertebrate abundance and diversity of herbicide management in genetically modified herbicide-tolerant winter-sown oilseed rape. Proc. R. Soc. B Biol. Sci. 272, 463-474.

Bosch, J., Kemp, W. P., 2002. Developing and establishing bee, species as crop pollinators: The example of Osmia spp. (Hymenoptera: Megachilidae) and fruit trees. Bull. Entomol. Res. 92, 3-16.

Botías, C., David, A., Hill, E. M., Goulson, D., 2016. Contamination of wild plants near neonicotinoid seedtreated crops, and implications for non-target insects. Sci. Total Environ. 566, 269-278.

Breeze, T. D., Bailey, A. P., Balcombe, K. G., Potts, S. G., 2014. Costing conservation: An expert appraisal of the pollinator habitat benefits of England's entry level stewardship. Biodivers. Conserv. 23, 11931214.

Breeze, Tom D., Boreux, V., Cole, L., Dicks, L., Klein, A., Pufal, G., Balzan, M. V., Bevk, D., Bortolotti, L., Petanidou, T., Mand, M., Pinto, M. A., Scheper, J., Stanisavljević, L., Stavrinides, M. C., Tscheulin, T., Varnava, A., Kleijn, D., 2019. Linking farmer and beekeeper preferences with ecological knowledge to improve crop pollination. People Nat. 1, 562-572.

Breeze, Tom D., Gallai, N., Garibaldi, L. A., Li, X. S., 2016. Economic Measures of Pollination Services: Shortcomings and Future Directions. Trends Ecol. Evol. 31, 927-939.

Britt, C., Tuffnell, N., Kirkham, F., Roberts, A., Sparks, T., 2011. Hedgerow Management: a survey of land managers' and contractors' practices and attitudes. Research report for the Department for Environment, Food and Rural Affairs DEFRA PROJECT BD2117, DEFRA.

Brittain, C. A., Vighi, M., Bommarco, R., Settele, J., Potts, S. G., 2010. Impacts of a pesticide on pollinator species richness at different spatial scales. Basic Appl. Ecol. 11, 106-115.

Buglife, 2020a. Urban Buzz. https://www.buglife.org.uk/our-work/pollinator-projects/urban-buzz/.

Buglife, 2020b. Landscape for Wild Pollinators and Farm Widlife Project. https://www.buglife.org.uk/projects/landscapes-for-wild-pollinators-and-farm-wildlife-project/.

Cardelus, C. L., Lowman, M. D., Eshete, A. W., 2012. Uniting Church and Science for Conservation. Science 335, 915-917.

Caron, P., Biénabe, E., Hainzelin, E., 2014. Making transition towards ecological intensification of agriculture a reality: the gaps in and the role of scientific knowledge. Curr Opin Env Sust. 8, 44-52.

Carvell, C., Bourke, A. F. G., Dreier, S., Freeman, S. N., Hulmes, S., Jordan, W. C., Redhead, J. W., Sumner, S., Wang, J., Heard, M. S., 2017. Bumblebee family lineage survival is enhanced in high-quality landscapes. Nature 543, 547-549.

Carvell, C., Bourke, A. F. G., Osborne, J. L., Heard, M. S., 2015. Effects of an agri-environment scheme on bumblebee reproduction at local and landscape scales. Basic Appl. Ecol. 16, 519-530.

CBD, 2013. Quick guides to the Aichi Biodiversity Targets Convention on Biological Diversity. 
https://www.cbd.int/doc/strategic-plan/targets/compilation-quick-guide-en.pdf.

CBD, 2016. Decision adopted by the Conference of the Parties to the Convention on Biological Diversity XIII/15. Implications of the IPBES assessment on pollinators, pollination and food production for the work of the Convention. https://www.cbd.int/doc/decisions/cop-13/cop-13-dec-15-en.pdf.

CBD, 2020. https://www.cbd.int/.

Cely-Santos, M., Lu, F., 2019. Intersections between rural livelihood security and animal pollination in Anolaima, Colombia. Geoforum 104, 13-24.

Cole, L. J., Brocklehurst, S., Robertson, D., Harrison, W., McCracken, D. I., 2015. Riparian buffer strips: Their role in the conservation of insect pollinators in intensive grassland systems. Agric. Ecosyst. Environ. 211, 207-220.

Cole, L. J., Kleijn, D., Dicks, L. V., Potts, S. G., Albrecht, M., Balzan, M. V., Bartomeous, I., Bebeli, P. J., Bevk, D., Biesmeijer, J. C., Chlebo, R., Dàutartë, A., Emmanouil, N., Hartfield, C., Holland, J. M., Holzdchuh, A., Knober, N. T., Kovács-Hostyânszki, A., Mandelik, Y., Panou, H., Paxton, R. J., Petanidou, T., Pinheriro de Varvalho, M. A. A., Rundlöf, M., Sarthou, J., Stavrinides, M. C., Suso, M. J., Szentgyörgyi, H., Vaissière, B. E., Varanva, A., Vilá, M., Zemeckis, R., Scheper, J., 2020. A critical analysis of the potential for EU Common Agricultural Policy measures to support wild pollinators on farmland. J. Appl. Ecol. 00, 1-14.

COLOSS, 2020. Colony Losses Monitoring. https://coloss.org/core-projects/colony-losses-monitoring/.

COM, 2018. 395 final EU Pollinators Initiative. https://eur-lex.europa.eu/legalcontent/EN/TXT/PDF/?uri=CELEX:52018DC0395\&from=EN.

Creissen, H. E., Jones, P. J., Tranter, R. B., Girling, R. D., Jess, S., Burnett, F. J., Gaffney, M., Thorne, F. S., Kildea, S., 2019. Measuring the unmeasurable? A method to quantify adoption of integrated pest management practices in temperate arable farming systems. Pest Manag. Sci. 75, 3144-3152.

DEFRA, 2019. Bees' Needs Champions Awards. https://www.gov.uk/government/news/bees-needschampions-awards-celebrate-pollinator-heroes.

DEFRA, 2019. National pollinator strategy: for bees and other pollinators in England. https://www.gov.uk/government/publications/national-pollinator-strategy-for-bees-and-otherpollinators-in-england.

Dover, J., Sotherton, N., Gobbett, K., 1990. Reduced pesticide inputs on cereal field margins: the effects on butterfly abundance. Ecol. Entomol. 15, 17-24.

Doyle, T., Hawkes, W. L. S., Massy, R., Powney, G. D., Menz, M. H. M., Wotton, K. R., 2020. Pollination by hoverflies in the Anthropocene. Proc. R. Soc. B. 287, 20200508.

Edwards, D. P., Laurance, S. G., 2012. Green labelling, sustainability and the expansion of tropical agriculture: Critical issues for certification schemes. Biol. Conserv. 151, 60-64.

European Commission., 2013. Regulation (EU) No 1308/2013 of the European Parliament and of the Council, establishing a common organisation of the markets in agricultural products and repealing Council Regulations (EEC) No 922/72, (EEC) No 234/79, (EC) No 1037/2001 and (EC) No 1234/2007. 
European Commission, 2020. The European Pollinator Initiative. https://ec.europa.eu/environment/nature/conservation/species/pollinators/index en.htm.

Fair to Nature, 2020. Conservation Grade. https://www.conservationgrade.org/.

FAO, 2013. FAO's Global Action on Pollination Services for Sustainable Agriculture - Tools and Guides. http://www.fao.org/pollination/resources/tools-and-guides/en/.

FAO, 2020. FAO's Global Action on Pollination Services for Sustainable Agriculture. http://www.fao.org/pollination/en.

Fisher, B., Turner, R. K., Morling, P., 2009. Defining and classifying ecosystem services for decision making. Ecol. Econ. 68, 643-653.

Free, J. B., Gennard, D., Stevenson, J. H., Williams, I. H., 1975. Beneficial insects present on a motorway verge. Biol. Conserv. 8, 61-72.

Garibaldi, L. A., Bartomeus, I., Bommarco, R., Klein, A. M., Cunningham, S. A., Aizen, M. A., Boreux, V., Garratt, M. P. D., Carvalheiro, L. G., Kremen, C., Morales, C. L., Schüepp, C., Chacoff, N. P., Freitas, B. M., Gagic, V., Holzschuh, A., Klatt, B. K., Krewenka, K. M., Krishnan, S., Mayfield, M. M., Motzke, E., Otieno, M., Petersen, J., Potts, S. G., Ricketts, T. H., Rundlöf, M., Sciligo, A., Sinu, P. A., SteffanDewenter, I., Taki, H., Tscharntke, T., Vergara, C. H., Viana, B. F., Woyciechowski, M., 2015. Trait matching of flower visitors and crops predicts fruit set better than trait diversity. J. Appl. Ecol. 52, 1436-1444.

Garibaldi, L. A., Gemmill-Herren, B., D’Annolfo, R., Graeub, B. E., Cunningham, S. A., Breeze, T. D., 2017. Farming Approaches for Greater Biodiversity, Livelihoods, and Food Security. Trends Ecol. Evol. 32, $68-80$.

Garibaldi, L. A., Pérez-Méndez, N., Garratt, M. P.D., Gemmill-Herren, B., Miguez, F. E., Dicks, L. V., 2019. Policies for Ecological Intensification of Crop Production. Trends Ecol. Evol. 34, 282-286.

Garibaldi, L. A., Steffan-Dewenter, I., Kremen, C., Morales, J. M., Bommarco, R., Cunningham, S. A., Carvalheiro, L. G., Chacoff, N. P., Dudenhoffer, J. H., Greenleaf, S. S., Holzschuh, A., Isaacs, R., Krewenka, K., Mandelik, Y., Mayfield, M. M., Morandin, L. A., Potts, S. G., Ricketts, T. H., Szentgyörgyi, H., Viana, B. F., Westphal, C., Winfree, R., Klein, A. M., 2011. Stability of pollination services decreases with isolation from natural areas despite honey bee visits. Ecol. Lett. 14, 1062-1072.

Garibaldi, L. A., Steffan-dewenter, I., Winfree, R., Aizen, M. A., Bommarco, R., Cunningham, S. A., Kremen, C., Carvalheiro, L. G., 2013. Honey Bee Abundance. Science 339, 1608-1611.

Garratt, M. P.D., Coston, D. J., Truslove, C. L., Lappage, M. G., Polce, C., Dean, R., Biesmeijer, J. C., Potts, S. G., 2014. The identity of crop pollinators helps target conservation for improved ecosystem services. Biol. Conserv. 169, 128-135.

Garratt, M. P.D., Potts, S. G., Banks, G., Hawes, C., Breeze, T. D., O’Connor, R. S., Carvell, C., 2019. Capacity and willingness of farmers and citizen scientists to monitor crop pollinators and pollination services. Glob. Ecol. Conserv. 20, e00781.

Garratt, Michael P.D., Senapathi, D., Coston, D. J., Mortimer, S. R., Potts, S. G., 2017. The benefits of 
hedgerows for pollinators and natural enemies depends on hedge quality and landscape context. Agric. Ecosyst. Environ. 247, 363-370.

Gill, R. J., Baldock, K. C. R., Brown, M. J. F., Cresswell, J. E., Dicks, L. V., Fountain, M. T., Garratt, M. P. D., Gough, L. A., Heard, M. S., Holland, J. M., Ollerton, J., Stone, G. N., Tang, C. Q., Vanbergen, A. J., Vogler, A. P., Woodward, G., Arce, A. N., Boatman, N. D., Brand-Hardy, R., Breeze, T. D., Green, M., Hartfield, C. M., O'Conner, R. S., Osborne, J. L., Phillips, J., Sutton, P. B., Potts, S. G., 2016. Protecting an Ecosystem Service: Approaches to Understanding and Mitigating Threats to Wild Insect Pollinators. Adv. Ecol. Res. 54, 135-206.

Godfray, H. C. J., Blacquière, T., Field, L. M., Hails, R. S., Petrokofsky, G., Potts, S. G., Raine, N. E., Vanbergen, A. J., McLean, A. R., 2014. A restatement of the natural science evidence base concerning neonicotinoid insecticides and insect pollinators. Proc. R. Soc. B Biol. Sci. 281, (1786).

Graystock, P., Blane, E. J., McFrederick, Q. S., Goulson, D., Hughes, W. O. H., 2016. Do managed bees drive parasite spread and emergence in wild bees? Int. J. Parasitol. Parasites Wildl. 5, 64-75.

Greater Bristol Pollian

Greenleaf, S. S., Williams, N. M., Winfree, R., Kremen, C., 2007. Bee foraging ranges and their relationship to body size. Oecologia 153, 589-596.

Guzman, A., Chase, M., Kremen, C., 2019. On-Farm Diversification in an Agriculturally-Dominated Landscape Positively Influences Specialist Pollinators. Front. Sustain. Food Syst. 3, (87).

Haaland, C., Naisbit, R. E., Bersier, L. F., 2011. Sown wildflower strips for insect conservation: A review. Insect Conserv. Divers. 4, 60-80.

Hall, D. M., Camilo, G. R., Tonietto, R. K., Ollerton, J., Ahrné, K., Arduser, M., Ascher, J. S., Baldock, K. C. R., Fowler, R., Frankie, G., Goulson, D., Gunnarsson, B., Hanley, M. E., Jackson, J. I., Langellotto, G., Lowenstein, D., Minor, E. S., Philpott, S. M., Potts, S. G., Sirohi, M. H., Spevak, E. M., Stone, G. N., Threlfall, C. G., 2017. The city as a refuge for insect pollinators. Conserv. Biol. 31, 24-29.

Hardman, C. J., Harrison, D. P. G., Shaw, P. J., Nevard, T. D., Hughes, B., Potts, S. G., Norris, K., $2016 a$. Supporting local diversity of habitats and species on farmland: A comparison of three wildlife-friendly schemes. J. Appl. Ecol. 53, 171-180.

Hardman, C. J., Norris, K., Nevard, T. D., Hughes, B., Potts, S. G., 2016b. Delivery of floral resources and pollination services on farmland under three different wildlife-friendly schemes. Agric. Ecosyst. Environ. 220, 142-151.

Harvey, J. A., Heinen, R., Armbrecht, I., Basset, Y., Baxter-Gilbert, J. H., Bezemer, T. M., Böhm, M., Bommarco, R., Borges, P. A. V., Cardoso, P., Clausnitzer, V., Cornelisse, T., Crone, E. E., Dicke, M., Dijkstra, K. D. B., Dyer, L., Ellers, J., Fartmann, T., Forister, M. L., Furlong, M. J., Garcia-Aguayo, A., Gerlach, J., Gols, R., Goulson, D., Habel, J. C., Haddad, N. M., Hallmann, C. A., Henriques, S., Herberstein, M. E., Hochkirch, A., Hughes, A. C., Jepsen, S., Jones, T. H., Kaydan, B. M., Kleijn, D., Klein, A. M., Latty, T., Leather, S. R., Lewis, S. M., Lister, B. C., Losey, J. E., Lowe, E. C., Macadam, C. R., Montoya-Lerma, J., Nagano, C. D., Ogan, S., Orr, M. C., Painting, C. J., Pham, T. H., Potts, S. G., Rauf, A., Roslin, T. L., Samways, M. J., Sanchez-Bayo, F., Sar, S. A., Schultz, C. B., Soares, A. O., Thancharoen, A., Tscharntke, T., Tylianakis, J. M., Umbers, K. D. L., Vet, L. E. M., Visser, M. E., Vujic, A., Wagner, D. L., WallisDeVries, M. F., Westphal, C., White, T. E., Wilkins, V. L., Williams, P. H., Wyckhuys, K. A. G., 
Zhu, Z. R., de Kroon, H., 2020. International scientists formulate a roadmap for insect conservation and recovery. Nat. Ecol. Evol. 4, 174-176.

Hass, A. L., Kormann, U. G., Tscharntke, T., Clough, Y., Baillod, A. B., Sirami, C., Fahrig, L., Martin, J. L., Baudry, J., Bertrand, C., Bosch, J., Brotons, L., Bure, F., Georges, R., Giralt, D., Marcos-García, M., Ricarte, A., Siriwardena, G., Batáry, P., 2018. Landscape configurational heterogeneity by small-scale agriculture, not crop diversity, maintains pollinators and plant reproduction in western Europe. Proc. R. Soc. B Biol. Sci. 285, (1872).

Herrick, C., 2017. New Program Highlights Bee-Friendly Farming Practices. American Fruit Grower.

Hertfordshire Pollinator Strategy, 2019. Hertfordshire county council 2019-2024. https://www.hertfordshire.gov.uk/media-library/documents/about-the-council/data-andinformation/pollinator-strategy.pdf.

Hill, R., Nates-Parra, G., Quezada-Euán, J. J. G., Buchori, D., LeBuhn, G., Maués, M. M., Pert, P. L., Kwapong, P. K., Saeed, S., Breslow, S. J., Carneiro da Cunha, M., Dicks, L. V., Galetto, L., Gikungu, M., Howlett, B. G., Imperatriz-Fonseca, V. L., O’B. Lyver, P., Martín-López, B., Oteros-Roza, E., Potts, S. G., Roué, M., 2019. Biocultural approaches to pollinator conservation. Nat. Sustain. 2, 214-222.

Holzschuh, A., Steffan-Dewenter, I., Tscharntke, T., 2008. Agricultural landscapes with organic crops support higher pollinator diversity. Oikos 117, 354-361.

lowa State University, 2013. Outreach Materials. https://www.ent.iastate.edu/pollinators/resources.

IPBES. 2016a. The assessment report of the Intergovernmental Science-Policy Platform on Biodiversity and Ecosystem Services on pollinators, pollination and food production. S. G. Potts, V. L. ImperatrizFonseca, and H. T. Ngo, (Eds). Secretariat of the Intergovernmental Science-Policy Platform on Biodiversity and Ecosystem Services, Bonn, Germany.

IPBES. 2016b. Summary for policymakers of the assessment report of the Intergovernmental SciencePolicy Platform on Biodiversity and Ecosystem Services on pollinators, pollination and food production. S.G. Potts, V. L. Imperatriz-Fonseca, H. T. Ngo, J. C. Biesmeijer, T. D. Breeze, L. V. Dicks, L. A. Garibaldi, R. Hill, J. Settele, A. J. Vanbergen, M. A. Aizen, S. A. Cunningham, C. Eardley, B. M. Freitas, N. Gallai, P.G. Kevan, A. Kovács-Hostyánszki, P.K. Kwapong, J. Li, X. Li., D.J. Martins, G. NatesParra, J.S. Pettis, R. Rader, and B. F. Viana (Eds.). Secretariat of the Intergovernmental Science-Policy Platform on Biodiversity and Ecosystem Services, Bonn, Germany.

IPBES. 2018. The IPBES assessment report on land degradation and restoration. Montanarella, L., Scholes, R., and Brainich, A. (Eds.). Secretariat of the Intergovernmental Science-Policy Platform on Biodiversity and Ecosystem Services, Bonn, Germany.

IUCN, 2020. https://www.iucn.org/.

Iverson, A. L., Gonthier, D. J., Pak, D., Ennis, K. K., Burnham, R. J., Perfecto, I., Ramos Rodriguez, M., Vandermeer, J. H., 2019. A multifunctional approach for achieving simultaneous biodiversity conservation and farmer livelihood in coffee agroecosystems. Biol. Conserv. 238, 108179.

Jacques, A., Laurent, M., Ribière-Chabert, M., Saussac, M., Bougeard, S., Budge, G. E., Hendrikx, P., Chauzat, M. P., 2017. A pan-European epidemiological study reveals honey bee colony survival 
depends on beekeeper education and disease control. PLoS One 12, 1-17.

Johansen, L., Westin, A., Wehn, S., luga, A., Ivascu, C. M., Kallioniemi, E., Lennartsson, T., 2019.

Traditional semi-natural grassland management with heterogeneous mowing times enhances flower resources for pollinators in agricultural landscapes. Glob. Ecol. Conserv. 18, e00619.

Jönsson, A. M., Ekroos, J., Dänhardt, J., Andersson, G. K. S., Olsson, O., Smith, H. G., 2015. Sown flower strips in southern Sweden increase abundances of wild bees and hoverflies in the wider landscape. Biol. Conserv. 184, 51-58.

Kennedy, C. M., Lonsdorf, E., Neel, M. C., Williams, N. M., Ricketts, T. H., Winfree, R., Bommarco, R., Brittain, C., Burley, A. L., Cariveau, D., Carvalheiro, L. G., Chacoff, N. P., Cunningham, S. A., Danforth, B. N., Dudenhöffer, J. H., Elle, E., Gaines, H. R., Garibaldi, L. A., Gratton, C., Holzschuh, A., Isaacs, R., Javorek, S. K., Jha, S., Klein, A. M., Kewenka, K., Mandelik, Y., Mayfield, M. M., Morandin, L., Neame, L. A., Otieno, M., Park, M., Potts, S. G., Rundlöf, M., Saez, A., Steffan-Dewenter, I., Taki, H., Viana, B. F., Westphal, C., Wilson, J. K., Greenleaf, S. S., Kremen, C., 2013. A global quantitative synthesis of local and landscape effects on wild bee pollinators in agroecosystems. Ecol. Lett. 16, 584-599.

Klatt, B. K., Holzschuh, A., Westphal, C., Clough, Y., Smit, I., Pawelzik, E., Tscharntke, T., 2014. Bee pollination improves crop quality, shelf life and commercial value. Proc. R. Soc. B Biol. Sci. 281, (1775).

Kleijn, D., Bommarco, R., Fijen, T. P. M., Garibaldi, L. A., Potts, S. G., Van der Putten, W. H., 2019. Ecological Intensification: Bridging the Gap between Science and Practice. Trends Ecol. Evol. 34, 154166.

Knapp, J. L., Bartlett, L. J., Osborne, J. L., 2017. Re-evaluating strategies for pollinator-dependent crops: How useful is parthenocarpy? J. Appl. Ecol. 54, 1171-1179.

Kovács-Hostyánszki, A., Espíndola, A., Vanbergen, A. J., Settele, J., Kremen, C., Dicks, L. V., 2017. Ecological intensification to mitigate impacts of conventional intensive land use on pollinators and pollination. Ecol. Lett. 20, 673-689.

Krishnan, S., Wiederkehr Guerra, G., Bertrand, D., Wertz-Kanounnikoff, S., Kettle, C. J., 2020. The pollination services of forests- $A$ review of forest and landscape interventions to enhance their crosssectoral benefits. Forestry Working Paper No. 15. Rome, FAO \& Bioversity International.

Lagerlöf, J., Stark, J., Svensson, B., 1992. Margins of agricultural fields as habitats for pollinating insects. Agric. Ecosyst. Environ. 40, 117-124.

Lawton, J.H., Brotherton, P.N.M., Brown, V.K., Elphick, C., Fitter, A.H., Forshaw, J., Haddow, R.W., Hilborne, S., Leafe, R.N., Mace, G.M., Southgate, M.P., Sutherland, W.J., Tew, T.E., Varley, J., Wynne, G. R., 2010. Making Space for Nature: A review of England's Wildlife Sites and Ecological Network. London, UK, DEFRA.

LEAF, 2020. LEAF Marque scheme. https://leafuk.org/farming/leaf-marque.

Lee, H., Sumner, D. A., Champetier, A., 2018. Pollination markets and the coupled futures of almonds and honey bees: Simulating impacts of shifts in demands and costs. Am. J. Agric. Econ. 101, 230-249.

Life Urban Green, 2018. https://www.lifeurbangreen.eu/. 
Lindström, S. A. M., Herbertsson, L., Rundlöf, M., Bommarco, R., Smith, H. G., 2016. Experimental evidence that honeybees depress wild insect densities in a flowering crop. Proc. R. Soc. B Biol. Sci. $283,1-8$.

Lusebrink, I., Girling, R. D., Farthing, E., Newman, T. A., Jackson, C. W., Poppy, G. M., 2015. The Effects of Diesel Exhaust Pollution on Floral Volatiles and the Consequences for Honey Bee Olfaction. J. Chem. Ecol. 41, 904-912.

M'Gonigle, L. K., Ponisio, L. C., Cutler, K., Kremen, C., 2015. Habitat restoration promotes pollinator persistence and colonization in intensively managed agriculture. Ecol. Appl. 25, 1557-1565.

M'Gonigle, L. K., Williams, N. M., Lonsdorf, E., Kremen, C., 2017. A Tool for Selecting Plants When Restoring Habitat for Pollinators. Conserv. Lett. 10, 105-111.

Maderson, S., Wynne-Jones, S., 2016. Beekeepers' knowledges and participation in pollinator conservation policy. J. Rural Stud. 45, 88-98.

Martin-Ortega, J., Ojea, E., Roux, C., 2013. Payments for water ecosystem services in Latin America: A literature review and conceptual model. Ecosyst. Serv. 6, 122-132.

Mcart, S. H., Fersch, A. A., Milano, N. J., Truitt, L. L., Böröczky, K., 2017. High pesticide risk to honey bees despite low focal crop pollen collection during pollination of a mass blooming crop. Sci. Rep. 7, 1-10.

McDougall, P., 2016. The Cost of New Agrochemical Product Discovery, Development and Registration in 1995, 2000 and 2005-8. R\&D Expenditure in 2014 and Expectations for 2019 Final Rep.

Ministry of the Environment, 2004. Government of Japan: Invasive Alien Species Act (Law No. 78 (June2, 2004)). https://www.env.go.jp/en/nature/as/040427.pdf.

Minnesota DNR, 2020. Roadsides for wildlife. https://www.dnr.state.mn.us/roadsidesforwildlife/index.html.

Montoya, J. E., Arnold, M. A., Rangel, J., Stein, L. R., Palma, M. A., 2020. Pollinator-attracting Companion Plantings Increase Crop Yield of Cucumbers and Habanero Peppers. HortScience 55, 164-169.

Moroń, D., Skórka, P., Lenda, M., Celary, W., Tryjanowski, P., 2017. Railway lines affect spatial turnover of pollinator communities in an agricultural landscape. Divers. Distrib. 23, 1090-1097.

Mukherjee, N., Hughe, J., Sunderland, W. J., McNeill, J., van Opstal, M., Dahdouh-Guebas, F. and Koedam N., 2015. The Delphi technique in ecology and biological conservation: applications and guidelines. Methods Ecol Evol. 6, 1097-1109.

National Biodiversity Data Centre, 2020. All-Ireland Pollinator Plan. https://pollinators.ie/.

The National Pollinator Garden Network, 2019. The Million Pollinator Garden Challenge. http://millionpollinatorgardens.org/.

Natural England, 2020. CLASS LICENCE: To permit the release of non-native sub species of bumblebee (Bombus terrestris) in commercial glass-houses for research. https://assets.publishing.service.gov.uk/government/uploads/system/uploads/attachment data/file /850679/cl34-non-native-bumblebees-release-in-glasshouses-licence.PDF. 
Newbold, T., Hudson, L. N., Arnell, A. P., Contu, S., De Palma, A., Ferrier, S., Hill, S. L. L., Hoskins, A. J., Lysenko, I., Phillips, H. R. P., Burton, V. J., Chng, C. W. T., Emerson, S., Gao, D., Pask-Hale, G., Hutton, J., Jung, M., Sanchez-Ortiz, K., Simmons, B. I., Whitmee, S., Zhang, H., Scharlemann, J. P. W., Purvis, A., 2016. Has land use pushed terrestrial biodiversity beyond the planetary boundary? A global assessment. Science 353, 288-291.

Nicholson, C. C., Ward, K. L., Williams, N. M., Isaacs, R., Mason, K. S., Wilson, J. K., Brokaw, J., Gut, L. J., Rothwell, N. L., Wood, T. J., Rao, S., Hoffman, G. D., Gibbs, J., Thorp, R. W., Ricketts, T. H., 2020. Mismatched outcomes for biodiversity and ecosystem services: testing the responses of crop pollinators and wild bee biodiversity to habitat enhancement. Ecol. Lett. 23, 326-335.

O'Sullivan, O. S., Holt, A. R., Warren, P. H., Evans, K. L., 2017. Optimising UK urban road verge contributions to biodiversity and ecosystem services with cost-effective management. J. Environ. Manage. 191, 162-171.

Öckinger, E., Winsa, M., Roberts, S. P. M., Bommarco, R., 2018. Mobility and resource use influence the occurrence of pollinating insects in restored seminatural grassland fragments. Restor. Ecol. 26, 873881.

Orford, K. A., Murray, P. J., Vaughan, I. P., Memmott, J., 2016. Modest enhancements to conventional grassland diversity improve the provision of pollination services. J. Appl. Ecol. 53, 906-915.

Park, M. G., Blitzer, E. J., Gibbs, J., Losey, J. E., Danforth, B. N., 2015. Negative effects of pesticides on wild bee communities can be buffered by landscape context. Proc. R. Soc. B Biol. Sci. 282, (1809).

Pereira, A. L. C., Taques, T. C., Valim, J. O. S., Madureira, A. P., Campos, W. G., 2015. The management of bee communities by intercropping with flowering basil (Ocimum basilicum) enhances pollination and yield of bell pepper (Capsicum annuum). J. Insect Conserv. 19, 479-486.

Phillips, B. B., Gaston, K. J., Bullock, J. M., Osborne, J. L., 2019. Road verges support pollinators in agricultural landscapes, but are diminished by heavy traffic and summer cutting. J. Appl. Ecol. 56, 2316-2327.

Philips, C., 2020. The force of Varroa: Anticipatory experiences in beekeeping biosecurity. J. Rural. Stud. 76, 58-66.

Pico-Mendoza, J., Pinoargote, M., Carrasco, B., Limongi Andrade, R., 2020. Ecosystem services in certified and non-certified coffee agroforestry systems in Costa Rica. Agroecol. Sustain. Food Syst. 00, $1-17$.

Pitts-Singer, T. L., Cane, J. H., 2011. The Alfalfa Leafcutting Bee, Megachile rotundata : The World's Most Intensively Managed Solitary Bee. Annu. Rev. Entomol. 56, 221-237.

Pollinator Partnership, 2020a. Ecoregional Planting Guides. https://www.pollinator.org/guides.

Pollinator Partnership, 2020b. About Bee Friendly Farming. https://www.pollinator.org/bff.

PoMS, 2020. UK Pollinator Monitoring Scheme. https://www.ceh.ac.uk/our-science/projects/pollinatormonitoring.

Potts, S. G., Imperatriz-Fonseca, V., Ngo, H. T., Aizen, M. A., Biesmeijer, J. C., Breeze, T. D., Dicks, L. V., 
Garibaldi, L. A., Hill, R., Settele, J., Vanbergen, A. J., 2016. Safeguarding pollinators and their values to human well-being. Nature 540, 220-229.

Prasifka, J. R., Mallinger, R. E., Portlas, Z. M., Hulke, B. S., Fugate, K. K., Paradis, T., Hampton, M. E., Carter, C. J., 2018. Using nectar-related traits to enhance crop-pollinator interactions. Front. Plant Sci. 9, 1-8.

Promote Pollinators, 2020. https://promotepollinators.org/.

Pywell, R. F., Heard, M. S., Woodcock, B. A., Hinsley, S., Ridding, L., Nowakowski, M., Bullock, J. M., 2015. Wildlife-friendly farming increases crop yield: Evidence for ecological intensification. Proc. R. Soc. B Biol. Sci. 282, (1816).

Reganold, J. P., Wachter, J. M., 2016. Organic agriculture in the twenty-first century. Nat. Plants 2, 15221.

Rehel, S., Varghese, A., Bradbear, N., Davidar, P., Roberts, S., Roy, P., Potts, S. G., 2009. Benefits of biotic pollination for non-Timber forest products and cultivated plants. Conserv. Soc. 7, 213-219.

Reitmayer, C. M., Ryalls J. M. W., Farthings, E., Jackson, C. W., Girling, R. D., Newman, T. A., 2019. Acute exposure to diesel exhaust induces central nervous system stress and altered learning and memory in honey bees. Sci Rep-UK. 9, 5793.

Rijksoverheid, 2018. Nationale Bijenstrategie Bed \& Breakfast for Bees. https://www.rijksoverheid.nl/documenten/rapporten/2018/01/22/nationale-bijenstrategie-bed-breakfast-for-bees.

River Revitalization Foundation Milwaukee, 2020. Milwaukee River Greenway. https://riverrevitalizationfoundation.org/public-greenspace/milwaukee-river-greenway/.

Rollin, O., Garibaldi, L. A., 2019. Impacts of honeybee density on crop yield: A meta-analysis. J. Appl. Ecol. 56, 1152-1163.

Roulston, T. H., Goodell, K., 2011. The Role of Resources and Risks in Regulating Wild Bee Populations. Annu. Rev. Entomol. 56, 293-312.

Rundlöf, M., Andersson, G. K. S., Bommarco, R., Fries, I., Hederström, V., Herbertsson, L., Jonsson, O., Klatt, B. K., Pedersen, T. R., Yourstone, J., Smith, H. G., 2015. Seed coating with a neonicotinoid insecticide negatively affects wild bees. Nature $521,77-80$.

Rusere, F., Mkuhlani, S., Crespo, O., Dicks, L. V., 2019. Developing pathways to improve smallholder agricultural productivity through ecological intensification technologies in semi-arid Limpopo, South Africa. Afr. J. Sci. Technol. Innov. Dev. 11, 543-553.

SAPOLL, 2019. Plan d'action pour les pollinateurs savauge. http://sapoll.eu/sapoll/le-resume/.

Scheper, J., Bommarco, R., Holzschuh, A., Potts, S. G., Riedinger, V., Roberts, S. P. M., Rundlöf, M., Smith, H. G., Steffan-Dewenter, I., Wickens, J. B., Wickens, V. J., Kleijn, D., 2015. Local and landscape-level floral resources explain effects of wildflower strips on wild bees across four European countries. J. Appl. Ecol. 52, 1165-1175. 
Scheper, J., Holzschuh, A., Kuussaari, M., Potts, S. G., Rundlöf, M., Smith, H. G., Kleijn, D., 2013. Environmental factors driving the effectiveness of European agri-environmental measures in mitigating pollinator loss - a meta-analysis. Ecol. Lett. 16, 912-920.

Scherr, S. J., McNeely, J. A., 2008. Biodiversity conservation and agricultural sustainability: Towards a new paradigm of "ecoagriculture" landscapes. Philos. Trans. R. Soc. B Biol. Sci. 363, 477-494.

Senapathi, D., Goddard, M. A., Kunin, W. E., Baldock, K. C. R., 2017. Landscape impacts on pollinator communities in temperate systems: evidence and knowledge gaps. Funct. Ecol. 31, 26-37.

Seufert, V., Ramankutty, N., Foley, J. A., 2012. Comparing the yields of organic and conventional agriculture. Nature 485, 229-232.

Sponsler, D. B., Grozinger, C. M., Hitaj, C., Rundlöf, M., Botías, C., Code, A., Lonsdorf, E. V., Melathopoulos, A. P., Smith, D. J., Suryanarayanan, S., Thogmartin, W. E., Williams, N. M., Zhang, M., Douglas, M. R., 2019. Pesticides and pollinators: A socioecological synthesis. Sci. Total Environ. 662, 1012-1027.

Stafford, J., 2018. Landscapes for Wild Pollinators. GWCT. https://www.gwct.org.uk/media/798834/08Jennie-Stafford.pdf.

Stanley, D. A., Garratt, M. P. D., Wickens, J. B., Wickens, V. J., Potts, S. G., Raine, N. E., 2015. Neonicotinoid pesticide exposure impairs crop pollination services provided by bumblebees. Nature $528,548-550$.

Steinhaur, N., Kulhanek, K., Antunez, K., Human, H., Chantawannakul, P., Chauzat, M-P., vanEngelsdorp D., 2018. Drivers of colony losses. Curr. Opin. Insect. Sci. 26, 142-148.

Stoner, K. A., 2016. Current pesticide risk assessment protocols do not adequately address differences between honey bees (apis mellifera) and bumble bees (bombus spp.). Front. Environ. Sci. 4, 1-8.

SUPER-B, 2018. http://superb-project.eu/.

Takeuchi, T., Takahashi, M., Nishimoto, M., Kiyoshi, T., Tsuchida, K., Nomura, T., Takahashi, J., 2018. Genetic structure of the bumble bee Bombus hypocrita sapporoensis, a potential domestic pollinator for crops in Japan. J. Apic. Res. 57, 203-212.

Thompson, H. M. and Hunt, L. V. 1999. Extrapolating from honeybees to bumblebees in pesticide risk assessment. Ecotoxicology 8, 147-166.

Trejo-Salazar, R. E., Eguiarte, L. E., 2016. Save Our Bats, Save Our Tequila: Industry and Science Join Forces to Help Bats and Agaves. Nat. Areas J. 36, 523-530.

Tscharntke, T., Clough, Y., Wanger, T. C., Jackson, L., Motzke, I., Perfecto, I., Vandermeer, J., Whitbread, A., 2012. Global food security, biodiversity conservation and the future of agricultural intensification. Biol. Conserv. 151, 53-59.

Tuck, S. L., Winqvist, C., Mota, F., Ahnström, J., Turnbull, L. A., Bengtsson, J., 2014. Land-use intensity and the effects of organic farming on biodiversity: A hierarchical meta-analysis. J. Appl. Ecol. 51, 746755. 
U.S.Fish and Wildlife Service, 2019. Outreach and Education Materials. https://www.fws.gov/pollinators/PollinatorPages/Outreach.html.

Vanbergen, A. J., Espíndola, A., Aizen, M. A., 2018. Risks to pollinators and pollination from invasive alien species. Nat. Ecol. Evol. 2, 16-25.

Vanbergen, A. J., Garratt, M. P., Vanbergen, A. J., Baude, M., Biesmeijer, J. C., Britton, N. F., Brown, M. J. F., Brown, M., Bryden, J., Budge, G. E., Bull, J. C., Carvell, C., Challinor, A. J., Connolly, C. N., Evans, D. J., Feil, E. J., Garratt, M. P., Greco, M. K., Heard, M. S., Jansen, V. AA., Keeling, M. J., Kunin, W. E., Marris, G. C., Memmott, J., Murray, J. T., Nicholson, S. W., Osborne, J. L., Paxton, R. J., Pirk, C. WW., Polce, C., Potts, S. G., Priest, N. K., Raine, N. E., Roberts, S., Ryabov, E. V., Sharfir, S., Shirley, M. DF., Simpson, S. J., Stevenson, P. C., Stone, G. N., Termansen, M., Wright, G. A., 2013. Threats to an ecosystem service: Pressures on pollinators. Front. Ecol. Environ. 11, 251-259.

van Lexmond, M. B., Bonmatin, J-M., Goulson, D., Noome, D. A., 2015. Worldwide integrated assessment on systemic pesticides. Environ. Sci. Pollut. Res. 22, 1-4.

Velthuis, H. H. W. and A. van Doorn. 2006. A century of advances in bumblebee domestication and the economic and environmental aspects of its commercialization for pollination. Apidologie. 37, 421451.

Vigie Nature, 2020. http://www.vigienature.fr/.

Villemey, A., Jeusset, A., Vargac, M., Bertheau, Y., Coulon, A., Touroult, J., Vanpeene, S., Castagneyrol, B., Jactel, H., Witte, I., Deniaud, N., Lachapelle, F. F. De, Jaslier, E., Roy, V., Guinard, E., Mitouard, E. Le., 2018. Can linear transportation infrastructure verges constitute a habitat and/or a corridor for insects in temperate landscapes? A systematic review. Environ. Evid. 7, 1-33.

Westphal, C., Steffan-Dewenter, I., Tscharntke, T., 2003. Mass flowering crops enhance pollinator densities at a landscape scale. Ecol. Lett. 6, 961-965.

Wilson, C., Tisdell, C., 2001. Why farmers continue to use pesticides despite environmental, health and sustainability costs. Ecol. Econ. 39, 449-462.

Winfree, R., Reilly, J. R., Bartomeus, I., Cariveau, D. P., Williams, N. M., Gibbs, J., 2018. Species turnover promotes the importance of bee diversity for crop pollination at regional scales. Science 359, 791793.

Winsa, M., Öckinger, E., Bommarco, R., Lindborg, R., Roberts, S. P. M., Wärnsberg, J., Bartomeus, I., 2017. Sustained functional composition of pollinators in restored pastures despite slow functional restoration of plants. Ecol. Evol. 7, 3836-3846.

Wojcik, V. A., Buchmann, S., 2012. POLLINATOR CONSERVATION AND MANAGEMENT ON ELECTRICAL TRANSMISSION AND ROADSIDE RIGHTS-OF-WAY: A REVIEW. J. Pollinat. Ecol. 7, 16-26.

Wood, T. J., Holland, J. M., Goulson, D., 2015. Pollinator-friendly management does not increase the diversity of farmland bees and wasps. Biol. Conserv. 187, 120-126.

Wood, T. J., Holland, J. M., Goulson, D., 2017. Providing foraging resources for solitary bees on farmland: current schemes for pollinators benefit a limited suite of species. J. Appl. Ecol. 54, 323-333. 
Woodcock, B. A., Isaac, N. J. B., Bullock, J. M., Roy, D. B., Garthwaite, D. G., Crowe, A., Pywell, R. F., 2016. Impacts of neonicotinoid use on long-term population changes in wild bees in England. Nat. Commun. 7, 12459.

World Trade Organisation, 1995. Agreement on Agriculture. https://www.wto.org/english/docs e/legal e/14-ag.pdf.

Wyckhuys, K. A. G., Bentley, J. W., Lie, R., Nghiem, L. T. P., Fredrix, M., 2018. Maximizing farm-level uptake and diffusion of biological control innovations in today's digital era. Biocontrol 63, 133-148.

Xerxes Society, 2020a. The Bee Better Certified ${ }^{\mathrm{TM}}$. https://beebettercertified.org/.

Xerxes Society, 2020b. Pollinator Conservation Programme. http://xerces.org/pollinator-conservation.

Zhang, H., Breeze, T., Bailey, A., Garthwaite, D., Harrington, R., Potts, S. G., 2017. Arthropod pest control for UK oilseed rape- Comparing insecticide efficacies, side effects and alternatives. PLoS One 12, 122. 
Table 1. Definitions of the five scales and their levels used in this study.

\begin{tabular}{|c|c|c|}
\hline Category & Level & Definition \\
\hline \multirow{5}{*}{$\begin{array}{l}\text { Spatial, the spatial scale at } \\
\text { which the response is most } \\
\text { effective }\end{array}$} & Field & $\begin{array}{l}\text { Area of cultivated land (enclosed or otherwise) which may be a few } \\
10 \text { s of } \mathrm{m}^{2} \text { to a few } 100 \text { ha in area }\end{array}$ \\
\hline & Farm & $\begin{array}{l}\text { Area of land comprising multiple fields and boundaries used for } \\
\text { crops and/or livestock and includes infrastructure such as buildings } \\
\text { and roads }\end{array}$ \\
\hline & Landscape & $\begin{array}{l}\text { Area of land often including multiple land uses (and sometimes } \\
\text { multiple farms) and typically several to several } 100 \mathrm{~km}^{2}\end{array}$ \\
\hline & National & Country \\
\hline & Global & Worldwide \\
\hline \multirow{4}{*}{$\begin{array}{l}\text { Temporal, the time scale at } \\
\text { which the response is most } \\
\text { effective }\end{array}$} & Season & $\begin{array}{l}\text { A period of time within the year marked by changes in weather, } \\
\text { ecology, and the amount of daylight (e.g. spring, monsoon), } \\
\text { typically a few weeks or months }\end{array}$ \\
\hline & Years & A period of time between 1 and a few years \\
\hline & Decades & A period of time of more than 10 but less than 30 years \\
\hline & Generation & A period of time more than 30 years \\
\hline \multirow{3}{*}{$\begin{array}{l}\text { Actors, the number of actors } \\
\text { (e.g. farmer, beekeeper, } \\
\text { nature reserve manager and } \\
\text { politician) needed for the } \\
\text { most effectively } \\
\text { implementing a response }\end{array}$} & Single & One actor group \\
\hline & Dual & Two actor groups \\
\hline & Multi & Three of more actor groups \\
\hline \multirow{4}{*}{$\begin{array}{l}\text { Social, the sphere (or scale) } \\
\text { of influence or motivation } \\
\text { that stimulates a response }\end{array}$} & $\begin{array}{l}\text { Individual/ self- } \\
\text { motivated }\end{array}$ & $\begin{array}{l}\text { Response self-motivated by individual without any external } \\
\text { influence }\end{array}$ \\
\hline & $\begin{array}{l}\text { Family/ peer- } \\
\text { network }\end{array}$ & $\begin{array}{l}\text { Response influenced by family members or peer network (including } \\
\text { friends, colleagues) }\end{array}$ \\
\hline & $\begin{array}{l}\text { Local } \\
\text { community }\end{array}$ & $\begin{array}{l}\text { Response influenced by local community (that could be the } \\
\text { neighbourhood, village, tribe or indigenous community that } \\
\text { individual belongs to) }\end{array}$ \\
\hline & Wider society & $\begin{array}{l}\text { Response influenced by the opinions and actions of wider society } \\
\text { (at national, regional or global scale) }\end{array}$ \\
\hline \multirow{5}{*}{$\begin{array}{l}\text { Sector, the sector(s) of } \\
\text { society (e.g. business, NGO, } \\
\text { policy and public) which } \\
\text { should be involved to } \\
\text { increase effectiveness }\end{array}$} & $\begin{array}{l}\text { Agri-food } \\
\text { business }\end{array}$ & $\begin{array}{l}\text { An amalgamation of market-based agricultural activities such as } \\
\text { farming and beekeeping and broader food activities such as } \\
\text { suppliers, retailers and processors }\end{array}$ \\
\hline & $\begin{array}{l}\text { Non-agri-food } \\
\text { business }\end{array}$ & $\begin{array}{l}\text { Other sectors of the economy such as energy generation, } \\
\text { manufacturing and media }\end{array}$ \\
\hline & Policy & $\begin{array}{l}\text { Governmental bodies whose actions directly affect economic } \\
\text { activity and consumption patterns }\end{array}$ \\
\hline & NGO & $\begin{array}{l}\text { Non-Governmental organizations involved in relevant } \\
\text { environmental or ecological activities as the basis for their } \\
\text { economic activities }\end{array}$ \\
\hline & Public & $\begin{array}{l}\text { The wider public whose activities fuel the economic activity of } \\
\text { other sectors }\end{array}$ \\
\hline
\end{tabular}


Table 2. Summary of the importance of different levels of scale for the effectiveness of a range of management and policy responses for pollinators and pollination included in the IPBES (2016a, b) global pollination assessment. For each category (spatial, temporal, actors, social and sector) the depth of shading indicates the relative level of importance assigned for each level within a category: no shading no importance or relevance (summed author scores 0-3); light shading - low or sum importance or relevance (summed author scores 4-7); and, dark shading - high importance or relevance (summed author scores 8-10). Summed scores for each cell are provided in Supplementary Materials (SM2).

\begin{tabular}{|c|c|c|c|c|c|c|c|c|c|c|c|c|c|c|c|c|c|c|c|c|c|c|}
\hline \multirow[b]{2}{*}{ 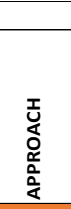 } & \multirow[b]{2}{*}{ RESPONSE } & \multicolumn{5}{|c|}{ Spatial } & \multicolumn{4}{|c|}{ Temporal } & \multicolumn{3}{|c|}{ Actors } & \multicolumn{4}{|c|}{ Social } & \multicolumn{5}{|c|}{ Sector } \\
\hline & & $\begin{array}{l}\frac{\pi}{0} \\
\frac{\pi}{4}\end{array}$ & \begin{tabular}{|l|} 
\\
ह \\
\end{tabular} & 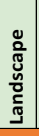 & $\begin{array}{l}\bar{\pi} \\
\stackrel{0}{0} \\
\stackrel{0}{\pi} \\
2\end{array}$ & $\begin{array}{l}\bar{\pi} \\
\text { 은 } \\
\text { U. }\end{array}$ & \begin{tabular}{|l|} 
\\
0 \\
$\tilde{J}$ \\
$\tilde{ٌ}$ \\
\end{tabular} & 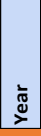 & 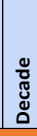 & 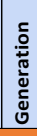 & $\begin{array}{l}\frac{0}{00} \\
\frac{5}{n}\end{array}$ & 嵒 & $\frac{\bar{z}}{5}$ & 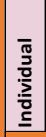 & 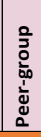 & 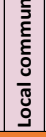 & 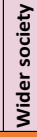 & 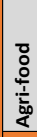 & 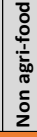 & 豙 & $\begin{array}{l}8 \\
\mathbf{0} \\
\end{array}$ & $\frac{u}{3}$ \\
\hline \multirow{16}{*}{ 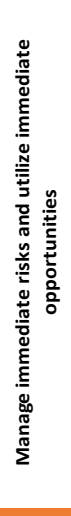 } & Create uncultivated patches of vegetation & & & & & & & & & & & & & & & & & & & & & \\
\hline & Manage blooming of mass-flowering crops & & & & & & & & & & & & & & & & & & & & & \\
\hline & Change management of grasslands & & & & & & & & & & & & & & & & & & & & & \\
\hline & Reward farmers for pollinator-friendly practices & & & & & & & & & & & & & & & & & & & & & \\
\hline & Inform farmers about pollination requirements & & & & & & & & & & & & & & & & & & & & & \\
\hline & Raise standards of pesticide and GMO risk assessment & & & & & & & & & & & & & & & & & & & & & \\
\hline & Practices to reduce pesticide drift and exposure & & & & & & & & & & & & & & & & & & & & & \\
\hline & Manage diseases and trade in managed pollinators & & & & & & & & & & & & & & & & & & & & & \\
\hline & Reduce pesticide use & & & & & & & & & & & & & & & & & & & & & \\
\hline & Support product certification and livelihood approaches & & & & & & & & & & & & & & & & & & & & & \\
\hline & Improve managed bee husbandry & & & & & & & & & & & & & & & & & & & & & \\
\hline & Develop alternative managed pollinators & & & & & & & & & & & & & & & & & & & & & \\
\hline & Quantify the benefits of managed pollinators & & & & & & & & & & & & & & & & & & & & & \\
\hline & Manage road verges & & & & & & & & & & & & & & & & & & & & & \\
\hline & Manage rights of way and vacant land in cities & & & & & & & & & & & & & & & & & & & & & \\
\hline & Plant breeding to reduce reliance on biotic pollination & & & & & & & & & & & & & & & & & & & & & \\
\hline \multirow{13}{*}{ 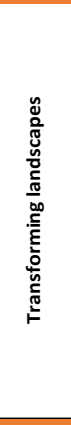 } & Support diversified farming systems & & & & & & & & & & & & & & & & & & & & & \\
\hline & Promote no-till agriculture & & & & & & & & & & & & & & & & & & & & & \\
\hline & Adapt farming to climate change & & & & & & & & & & & & & & & & & & & & & \\
\hline & Collaborative approaches to landscape management & & & & & & & & & & & & & & & & & & & & & \\
\hline & Promote IPM & & & & & & & & & & & & & & & & & & & & & \\
\hline & Monitor and evaluate pollination on farms & & & & & & & & & & & & & & & & & & & & & \\
\hline & Establish payment for pollination services schemes & & & & & & & & & & & & & & & & & & & & & \\
\hline & Develop markets for alternative managed pollinators & & & & & & & & & & & & & & & & & & & & & \\
\hline & Traditional and knowledge co-production for habitat management & & & & & & & & & & & & & & & & & & & & & \\
\hline & Support "biocultural diversity" conservation approaches & & & & & & & & & & & & & & & & & & & & & \\
\hline & Restore natural habitats & & & & & & & & & & & & & & & & & & & & & \\
\hline & Protect heritage sites and practices & & & & & & & & & & & & & & & & & & & & & \\
\hline & Increase connectivity between habitat patches & & & & & & & & & & & & & & & & & & & & & \\
\hline \multirow{9}{*}{ 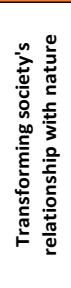 } & Translate pollinator research into agricultural practices & & & & & & & & & & & & & & & & & & & & & \\
\hline & Support knowledge co-production and exchange & & & & & & & & & & & & & & & & & & & & & \\
\hline & Strengthen Indigenous and Local Knowledge & & & & & & & & & & & & & & & & & & & & & \\
\hline & Support market based solutions and innovations & & & & & & & & & & & & & & & & & & & & & \\
\hline & Monitor pollinators & & & & & & & & & & & & & & & & & & & & & \\
\hline & Increase taxonomic expertise & & & & & & & & & & & & & & & & & & & & & \\
\hline & Education and outreach programmes & & & & & & & & & & & & & & & & & & & & & \\
\hline & Manage urban spaces for pollinators and collaborative pathways & & & & & & & & & & & & & & & & & & & & & \\
\hline & Support high-level pollination initiatives and strategies & & & & & & & & & & & & & & & & & & & & & \\
\hline
\end{tabular}




\section{Supplementary Online Materials 1.}

Short names used in this paper and full names from the IPBES 2016b report.

\begin{tabular}{|c|c|}
\hline Short name & Full name used in IPBES 2016b \\
\hline Create uncultivated patches of vegetation & $\begin{array}{l}\text { Create uncultivated patches of vegetation such as field } \\
\text { margins with extended flowering periods }\end{array}$ \\
\hline Manage blooming of mass-flowering crops & Manage blooming of mass-flowering crops \\
\hline Change management of grasslands & Change management of grasslands \\
\hline Reward farmers for pollinator-friendly practices & Reward farmers for pollinator-friendly practices \\
\hline Inform farmers about pollination requirements & Inform farmers about pollination requirements \\
\hline Raise standards of pesticide and GMO risk assessment & $\begin{array}{l}\text { Raise standards of pesticide and genetically modified } \\
\text { organism (GMO) risk assessment }\end{array}$ \\
\hline Practices to reduce pesticide drift and exposure & $\begin{array}{l}\text { Develop and promote the use of technologies that reduce } \\
\text { pesticide drift and agricultural practices that reduce } \\
\text { exposure to pesticides }\end{array}$ \\
\hline Manage diseases and trade in managed pollinators & $\begin{array}{l}\text { Prevent infections and treat diseases of managed } \\
\text { pollinators; regulate trade in managed pollinators }\end{array}$ \\
\hline Reduce pesticide use & Reduce pesticide use \\
\hline Support product certification and livelihood approaches & Support product certification and livelihood approaches \\
\hline Improve managed bee husbandry & Improve managed bee husbandry \\
\hline Develop alternative managed pollinators & Develop alternative managed pollinators \\
\hline Quantify the benefits of managed pollinators & Quantify the benefits of managed pollinators \\
\hline Manage road verges & Manage road verges \\
\hline Manage rights of way and vacant land in cities & $\begin{array}{l}\text { Manage rights of way and vacant land in cities to support } \\
\text { pollinators }\end{array}$ \\
\hline Plant breeding to reduce reliance on biotic pollination & $\begin{array}{l}\text { Plant breeding solutions to reduce reliance on biotic } \\
\text { pollination }\end{array}$ \\
\hline Support diversified farming systems & Support diversified farming systems \\
\hline Promote no-till agriculture & Promote no-till agriculture \\
\hline Adapt farming to climate change & Adapt farming to climate change \\
\hline Collaborative approaches to landscape management & $\begin{array}{l}\text { Encourage farmers to work together to plan landscapes; } \\
\text { engage communities (participatory management) }\end{array}$ \\
\hline Promote IPM & $\begin{array}{l}\text { Promote Integrated Pest Management (IPM) and pesticide } \\
\text { management }\end{array}$ \\
\hline Monitor and evaluate pollination on farms & Monitor and evaluate pollination on farms \\
\hline Establish payment for pollination services schemes & Establish payment for pollination services schemes \\
\hline Develop markets for alternative managed pollinators & $\begin{array}{l}\text { Develop and build markets for alternative managed } \\
\text { pollinators }\end{array}$ \\
\hline $\begin{array}{l}\text { Traditional and knowledge co-production for habitat } \\
\text { management }\end{array}$ & $\begin{array}{l}\text { Support traditional practices for managing habitat } \\
\text { patchiness, crop rotation and co-production of knowledge } \\
\text { between indigenous and local knowledge holders, scientists } \\
\text { and stakeholders }\end{array}$ \\
\hline Support "biocultural diversity" conservation approaches & $\begin{array}{l}\text { Support "biocultural diversity" conservation approaches, } \\
\text { recognition of rights, tenure and strengthening of ILK }\end{array}$ \\
\hline Restore natural habitats & Restore natural habitats (also in urban areas) \\
\hline Protect heritage sites and practices & Protect heritage sites and practices \\
\hline Increase connectivity between habitat patches & Increase connectivity between habitat patches \\
\hline Translate pollinator research into agricultural practices & Translate pollinator research into agricultural practices \\
\hline Support knowledge co-production and exchange & $\begin{array}{l}\text { Support knowledge co-production and exchange among } \\
\text { indigenous and local knowledge holders, scientists and } \\
\text { stakeholders }\end{array}$ \\
\hline Strengthen Indigenous and Local Knowledge & $\begin{array}{l}\text { Strengthen ILK that fosters pollinators and pollination, and } \\
\text { knowledge exchange among researchers and stakeholders }\end{array}$ \\
\hline Support market based solutions and innovations & Support innovative pollinator activities that engage \\
\hline
\end{tabular}




\begin{tabular}{|l|l|}
\hline & $\begin{array}{l}\text { stakeholders with attachments to the multiple socio- } \\
\text { cultural values of pollinators and market based solutions } \\
\text { and innovations }\end{array}$ \\
\hline Monitor pollinators & $\begin{array}{l}\text { Monitor pollinators (collaboration between farmers, the } \\
\text { broader community and pollinator experts) }\end{array}$ \\
\hline Increase taxonomic expertise & $\begin{array}{l}\text { Increase taxonomic expertise through education, training } \\
\text { and technology }\end{array}$ \\
\hline Education and outreach programmes & Education and outreach programmes \\
\hline $\begin{array}{l}\text { Manage urban spaces for pollinators and collaborative } \\
\text { pathways }\end{array}$ & $\begin{array}{l}\text { Manage urban spaces for pollinators and collaborative } \\
\text { pathways }\end{array}$ \\
\hline Support high-level pollination initiatives and strategies & Support high-level pollination initiatives and strategies \\
\hline
\end{tabular}




\section{Supplementary Online Materials 2.}

Changes made from original scoring based on group discussion of the evidence:

- Inform farmers about pollination requirements: Actors - Multi cell rescored to 7 (from 2)

- Raise standards of pesticide and GMO risk assessment: Spatial - Global cell rescored to 8 (from 4)

- Practices to reduce pesticide drift and exposure: Temporal - Season cell scored to 8 (from 4)

- Practices to reduce pesticide drift and exposure: Temporal - Decade cell scored to 7 (from 5)

- Manage road verges: Actors - Multi cell rescored to 8 (from 6)

- Protect heritage sites and practices: Spatial - Global cell rescored to 7 (from 4)

All other cells remained unchanged. 


\begin{tabular}{|c|c|c|c|c|c|c|c|c|c|c|c|c|c|c|c|c|c|c|c|c|c|c|}
\hline \multirow[b]{2}{*}{ 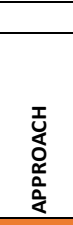 } & \multirow[b]{2}{*}{ RESPONSE } & \multicolumn{5}{|c|}{ Spatial } & \multicolumn{4}{|c|}{ Temporal } & \multicolumn{3}{|c|}{ Actors } & \multicolumn{4}{|c|}{ Social } & \multicolumn{5}{|c|}{ Sector } \\
\hline & & $\frac{\pi}{i}$ & 息 & 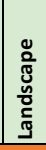 & $\begin{array}{l}\bar{\pi} \\
\stackrel{0}{0} \\
\stackrel{0}{+} \\
\text { त } \\
2\end{array}$ & 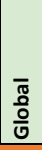 & 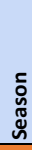 & 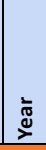 & 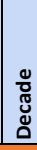 & 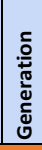 & $\begin{array}{l}\frac{0}{00} \\
\stackrel{5}{n}\end{array}$ & $\begin{array}{l}\overline{0} \\
\overline{3}\end{array}$ & 吾 & 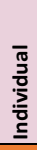 & 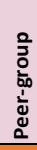 & 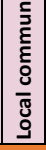 & 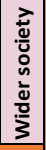 & 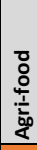 & 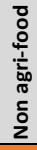 & 응 & 엄 & 늠 \\
\hline \multirow{16}{*}{ 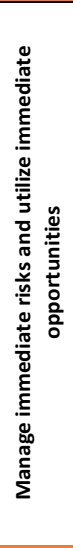 } & Create uncultivated patches of vegetation & 10 & 10 & 8 & 0 & 0 & 10 & 9 & 4 & 0 & 10 & 5 & 1 & 10 & 7 & 5 & 1 & 10 & 1 & 7 & 3 & 2 \\
\hline & Manage blooming of mass-flowering crops & 7 & 10 & 10 & 1 & 1 & 10 & 9 & 2 & 0 & 10 & 3 & 2 & 10 & 7 & 1 & 0 & 10 & 1 & 4 & 1 & 1 \\
\hline & Change management of grasslands & 7 & 10 & 9 & 3 & 0 & 6 & 9 & 8 & 1 & 9 & 4 & 1 & 9 & 8 & 3 & 0 & 9 & 0 & 6 & 3 & 3 \\
\hline & Reward farmers for pollinator-friendly practices & 8 & 10 & 10 & 6 & 1 & 6 & 10 & 7 & 1 & 7 & 4 & 2 & 9 & 9 & 2 & 3 & 10 & 2 & 9 & 1 & 2 \\
\hline & Inform farmers about pollination requirements & 2 & 10 & 3 & 2 & 0 & 7 & 10 & 2 & 0 & 10 & 0 & 7* & 9 & 6 & 0 & 1 & 10 & 1 & 9 & 1 & 0 \\
\hline & Raise standards of pesticide and GMO risk assessment & 2 & 5 & 5 & 5 & $8^{*}$ & 4 & 8 & 8 & 0 & 8 & 0 & 2 & 2 & 2 & 0 & 8 & 6 & 2 & 10 & 0 & 1 \\
\hline & Practices to reduce pesticide drift and exposure & 8 & 10 & 5 & 2 & 0 & $8^{*}$ & 8 & $5^{*}$ & 2 & 10 & 1 & 2 & 6 & 5 & 2 & 5 & 9 & 4 & 5 & 1 & 2 \\
\hline & Manage diseases and trade in managed pollinators & 0 & 1 & 7 & 10 & 6 & 2 & 8 & 8 & 0 & 4 & 7 & 3 & 4 & 9 & 4 & 2 & 6 & 2 & 10 & 2 & 0 \\
\hline & Reduce pesticide use & 4 & 10 & 10 & 10 & 6 & 3 & 9 & 10 & 4 & 9 & 6 & 4 & 8 & 8 & 4 & 8 & 10 & 3 & 9 & 3 & 4 \\
\hline & Support product certification and livelihood approaches & 1 & 6 & 3 & 7 & 1 & 1 & 6 & 8 & 2 & 2 & 2 & 8 & 3 & 5 & 8 & 10 & 9 & 4 & 5 & 6 & 5 \\
\hline & Improve managed bee husbandry & 0 & 0 & 2 & 10 & 2 & 0 & 10 & 9 & 1 & 5 & 8 & 0 & 8 & 10 & 2 & 0 & 4 & 7 & 5 & 5 & 2 \\
\hline & Develop alternative managed pollinators & 1 & 3 & 2 & 8 & 3 & 0 & 7 & 10 & 1 & 5 & 8 & 0 & 3 & 10 & 6 & 0 & 7 & 9 & 4 & 2 & 1 \\
\hline & Quantify the benefits of managed pollinators & 7 & 9 & 4 & 1 & 1 & 8 & 9 & 4 & 0 & 9 & 2 & 1 & 7 & 6 & 2 & 0 & 8 & 2 & 4 & 0 & 0 \\
\hline & Manage road verges & 0 & 1 & 9 & 7 & 0 & 6 & 9 & 6 & 1 & 2 & 1 & $8^{*}$ & 0 & 2 & 7 & 9 & 3 & 6 & 8 & 4 & 2 \\
\hline & Manage rights of way and vacant land in cities & 0 & 1 & 9 & 9 & 0 & 6 & 9 & 7 & 0 & 3 & 2 & 8 & 0 & 5 & 8 & 7 & 1 & 8 & 7 & 5 & 4 \\
\hline & Plant breeding to reduce reliance on biotic pollination & 0 & 3 & 8 & 7 & 2 & 1 & 7 & 7 & 1 & 8 & 7 & 3 & 3 & 9 & 5 & 0 & 10 & 1 & 2 & 0 & 0 \\
\hline \multirow{13}{*}{ 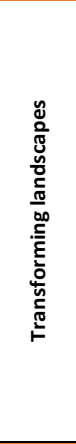 } & Support diversified farming systems & 4 & 9 & 10 & 4 & 0 & 4 & 8 & 10 & 0 & 8 & 2 & 2 & 8 & 10 & 2 & 2 & 10 & 2 & 9 & 1 & 1 \\
\hline & Promote no-till agriculture & 9 & 10 & 4 & 0 & 0 & 8 & 9 & 5 & 0 & 8 & 2 & 0 & 8 & 10 & 0 & 0 & 10 & 0 & 5 & 1 & 0 \\
\hline & Adapt farming to climate change & 4 & 10 & 10 & 9 & 4 & 3 & 5 & 10 & 7 & 7 & 1 & 4 & 5 & 9 & 8 & 7 & 10 & 8 & 10 & 7 & 6 \\
\hline & Collaborative approaches to landscape management & 3 & 6 & 8 & 3 & 0 & 3 & 10 & 9 & 1 & 1 & 8 & 7 & 4 & 10 & 8 & 0 & 10 & 3 & 7 & 4 & 2 \\
\hline & Promote IPM & 4 & 10 & 8 & 3 & 0 & 4 & 10 & 4 & 0 & 10 & 0 & 2 & 10 & 10 & 1 & 2 & 10 & 1 & 8 & 1 & 1 \\
\hline & Monitor and evaluate pollination on farms & 5 & 10 & 3 & 3 & 1 & 8 & 10 & 4 & 1 & 10 & 1 & 2 & 9 & 10 & 1 & 0 & 8 & 1 & 7 & 1 & 1 \\
\hline & Establish payment for pollination services schemes & 0 & 10 & 8 & 6 & 0 & 3 & 10 & 6 & 0 & 1 & 6 & 5 & 7 & 8 & 5 & 7 & 8 & 3 & 10 & 2 & 2 \\
\hline & Develop markets for alternative managed pollinators & 0 & 3 & 2 & 6 & 4 & 1 & 5 & 6 & 2 & 2 & 6 & 1 & 1 & 8 & 0 & 0 & 8 & 1 & 2 & 0 & 0 \\
\hline & Traditional and knowledge co-production for habitat management & 4 & 9 & 10 & 8 & 2 & 2 & 9 & 9 & 5 & 1 & 5 & 10 & 4 & 10 & 10 & 5 & 8 & 10 & 6 & 8 & 5 \\
\hline & Support "biocultural diversity" conservation approaches & 2 & 3 & 7 & 9 & 3 & 4 & 10 & 8 & 0 & 0 & 4 & 8 & 1 & 5 & 9 & 10 & 4 & 6 & 8 & 8 & 7 \\
\hline & Restore natural habitats & 2 & 5 & 10 & 8 & 4 & 8 & 10 & 5 & 2 & 2 & 3 & 8 & 5 & 9 & 8 & 7 & 4 & 6 & 8 & 10 & 7 \\
\hline & Protect heritage sites and practices & 0 & 1 & 6 & 9 & 7* & 2 & 9 & 10 & 2 & 2 & 5 & 8 & 4 & 6 & 10 & 8 & 4 & 6 & 9 & 9 & 5 \\
\hline & Increase connectivity between habitat patches & 1 & 8 & 10 & 6 & 1 & 0 & 7 & 10 & 3 & 3 & 8 & 8 & 3 & 10 & 7 & 3 & 8 & 4 & 9 & 5 & 3 \\
\hline \multirow{9}{*}{ 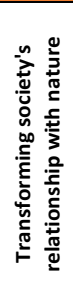 } & Translate pollinator research into agricultural practices & 2 & 3 & 6 & 10 & 5 & 1 & 5 & 10 & 6 & 1 & 3 & 8 & 1 & 7 & 5 & 7 & 9 & 7 & 9 & 3 & 1 \\
\hline & Support knowledge co-production and exchange & 0 & 1 & 8 & 10 & 5 & 0 & 4 & 9 & 8 & 0 & 0 & 10 & 0 & 8 & 9 & 2 & 7 & 7 & 6 & 6 & 4 \\
\hline & Strengthen Indigenous and Local Knowledge & 0 & 0 & 4 & 10 & 5 & 0 & 3 & 8 & 8 & 0 & 0 & 10 & 0 & 6 & 9 & 3 & 6 & 5 & 8 & 5 & 4 \\
\hline & Support market based solutions and innovations & 0 & 0 & 7 & 10 & 4 & 0 & 4 & 10 & 6 & 0 & 0 & 10 & 0 & 8 & 9 & 4 & 6 & 8 & 6 & 8 & 7 \\
\hline & Monitor pollinators & 2 & 8 & 10 & 10 & 4 & 1 & 7 & 10 & 6 & 0 & 0 & 10 & 1 & 7 & 8 & 8 & 8 & 5 & 10 & 10 & 9 \\
\hline & Increase taxonomic expertise & 0 & 0 & 1 & 10 & 5 & 0 & 2 & 10 & 9 & 2 & 4 & 5 & 8 & 7 & 6 & 0 & 2 & 6 & 5 & 10 & 3 \\
\hline & Education and outreach programmes & 0 & 0 & 5 & 10 & 2 & 0 & 6 & 10 & 9 & 0 & 4 & 10 & 3 & 6 & 7 & 8 & 5 & 7 & 6 & 8 & 9 \\
\hline & Manage urban spaces for pollinators and collaborative pathways & 0 & 0 & 8 & 8 & 1 & 0 & 6 & 9 & 5 & 0 & 6 & 8 & 3 & 6 & 9 & 6 & 0 & 8 & 8 & 8 & 8 \\
\hline & Support high-level pollination initiatives and strategies & 0 & 0 & 1 & 10 & 8 & 0 & 2 & 10 & 10 & 0 & 0 & 10 & 0 & 0 & 3 & 10 & 7 & 6 & 10 & 7 & 6 \\
\hline
\end{tabular}

